\title{
An integrated sequence stratigraphic, palaeoenvironmental, and chronostratigraphic analysis of the Tangahoe Formation, southern Taranaki coast, with implications for mid-Pliocene (c. 3.4-3.0 Ma) glacio-eustatic sea-level changes
}

\author{
Tim R. Naish ${ }^{1}$, Florian Wehland ${ }^{2}$, Gary S. Wilson ${ }^{3}$ Greg H. Browne, \\ Richard A. Cook ${ }^{1}$, Hugh E. G. Morgans ${ }^{1}$, Michael Rosenberg ${ }^{1}$, Peter R. King ${ }^{1}$, \\ David Smale ${ }^{4}$, Campbell S. Nelson ${ }^{5}$, Peter J. J. Kamp ${ }^{5}$, and Brian Ricketts ${ }^{6}$
}

\begin{abstract}
Sediments of the mid-Pliocene (c. 3.4-3.0 Ma) Tangahoe Formation exposed in cliffs along the South Taranaki coastline of New Zealand comprise a $270 \mathrm{~m}$ thick, cyclothemic shallow-marine succession that has been gently warped into a north to south trending, low angle anticline. This study examines the sedimentologic, faunal, and petrographic characteristics of 10 Milankovitch-scale (6th order), shallow-marine depositional sequences exposed on the western limb of the anticline. The sequences are recognised on the basis of the cyclic vertical stacking of their constituent lithofacies, which are bound by sharp wave cut surfaces produced during transgressive shoreface erosion. Each sequence comprises three parts: (1) a 0.2-2 m thick, deepening upwards, basal suite of reworked bioclastic lag deposits (onlap shellbed) and/or an overlying matrix supported, molluscan shellbed of offshore shelf affinity (backlap shellbed); (2) a 5-20 m thick, gradually shoaling, aggradational siltstone succession; and (3) a 5-10 m thick, strongly progradational, well sorted "forced regressive" shoreline sandstone. The three-fold subdivision corresponds to transgressive, highstand, and regressive systems tracts (TSTs, HSTs, and RSTs) respectively, and represents deposition during a glacioeustatic sea-level cycle. Lowstand systems tract sediments are not recorded because the outcrop is situated c. $100 \mathrm{~km}$ east of the contemporary shelf edge and was subaerially exposed at that time. Well developed, sharp- and gradational-based forced regressive sandstones contain a variety of storm-emplaced sedimentary structures, and represent the rapid and abrupt basinward translation of the shoreline on to a storm dominated, shallow shelf during eustatic sea-level fall. Increased supply of sediment from north-west South Island during "forced regression" is indicated from petrographic analyses of the heavy mineralogy of the sandstones. A chronology based on biostratigraphy and the correlation
\end{abstract}

\footnotetext{
${ }^{1}$ Institute of Geological and Nuclear Sciences, P.O. Box 30 368, Lower Hutt, New Zealand.

${ }^{2}$ Institut fur Geologie und Paleontologie, Abt Geophysik, University of Tuebingen, Sigwartstrabe 10, 72076 Tuebingen, Germany.

${ }^{3}$ Department of Earth Sciences, University of Oxford, Parks Road, Oxford OX1 3PR, United Kingdom. Present address: Department of Geology, University of Otago, P.O. Box 56, Dunedin, New Zealand. ${ }^{4}$ Petrographic Profiles, 28 Bronte Street, Nelson 7001, New Zealand.

${ }^{5}$ Department of Earth Sciences, The University of Waikato, Private Bag 3105, Hamilton, New Zealand.

${ }^{6}$ Department of Geology, The University of Auckland, Private Bag 92 019, Auckland, New Zealand. R05008 Received 12 May 2005; accepted 25 May 2005; Online publication date 27 July 2005
} 
of a new magnetostratigraphy to the magnetic polarity timescale allows: (1) identification of the Mammoth (C2An.2r) and Kaena (C2An.1r) subchrons; (2) correlation of the coastal section to the Waipipian Stage; and (3) estimation of the age of the coastal section as 3.36-3.06 Ma. Qualitative assessment of foraminiferal census data and molluscan palaeoecology reveals cyclic changes in water depth from shelf to shoreline environments during the deposition of each sequence. Seven major cycles in water depth of between 20 and $50 \mathrm{~m}$ have been correlated to individual $40 \mathrm{ka}$ glacio-eustatic sea-level cycles on the marine oxygen isotope timescale. The coastal Tangahoe Formation provides a shallow-marine record of global glacio-eustasy prior to the development of significant ice sheets on Northern Hemisphere continents, and supports evidence from marine $\delta^{18} \mathrm{O}$ archives that changes in Antarctic ice volume were occurring during the Pliocene.

Keywords Tangahoe Formation; Wanganui Basin; Taranaki Basin; mid-Pliocene; sequence stratigraphy; sea level; forced regression; magnetostratigraphy; chronostratigraphy

\section{INTRODUCTION}

The mid-Pliocene (c. 3.4-3.0 Ma) Tangahoe Formation exposed in coastal cliffs between Hawera and Patea lies on the poorly defined boundary that separates eastern parts of Taranaki and Wanganui Basins, western North Island, New Zealand (Fig. 1). Both basins share a common depositional history in the late Neogene, and the coastal section is ideally located to provide a window into the evolution of the western North Island continental margin. Northward progradation of the continental margin during the Early Pliocene culminated with deposition of the shallow-marine Matemateaonga Formation building an extensive continental shelf from the Manaia Anticline in the west to the present day position of the Ruahine Ranges to the east. Ensuing deposition of the Tangahoe Formation coincided with the onset of rapid subsidence and regional flooding of the Early Pliocene shelf in response to changes in eastern North Island subduction geometry (Kamp et al. 2002). A bathyal depocentre rapidly evolved in north-eastern parts of Wanganui Basin, while a regressive wedge of shallow-marine strata prograded from the south-west through the study area. East of the coastal section and towards the Whanganui River valley, Tangahoe Formation shelf sediments pass into slope mudstone and channelised redeposited sandstone (Hayton 1998; Vonk et al. 2002).

This study presents an integrated analysis of shelf sediments within the mid-Pliocene part of this progradational depositional system, and contributes to a wider regional synthesis of the Pliocene-Pleistocene geology of Wanganui and eastern Taranaki Basins being undertaken by researchers at The University of Waikato (Kamp et al. "The geology of Wanganui Basin and its petroleum systems" in prep.). The sediments are spectacularly exposed on the western limb of a low angle regional anticline between Mangaroa and Inaha Streams (Fig. 2, 3). We report on the sedimentological, faunal, and petrographic characteristics of 10 Milankovitchscale (6th order), shallow-marine sequences, and present a new magnetostratigraphy for the coastal outcrop section (Fig. 4). Three sedimentary sequences are selected for a detailed analysis of proxy environmental data including: (1) grain size, which is a qualitative indicator of changes in palaeowater depth; (2) gamma ray, which highlights clay rich radiogenic intervals often associated with maximum water depths; (3) percentage calcium carbonate as a measure of sedimentation rate; and (4) sand petrography for identifying potential changes in sediment provenance during sea-level changes. Collectively, these proxy data aid reconstruction of environmental changes during eustatic sea-level changes. Raw data which underpin interpretations presented in this paper are available on www.gns.cri.nz/. Our sequence analysis and chronostratigraphic framework provide an opportunity to evaluate the development of the palaeoshelf system, and to constrain palaeobathymetric changes, during orbitally controlled $40 \mathrm{ka}$ sea-level cycles. We outline the stratal response of the western North Island continental 


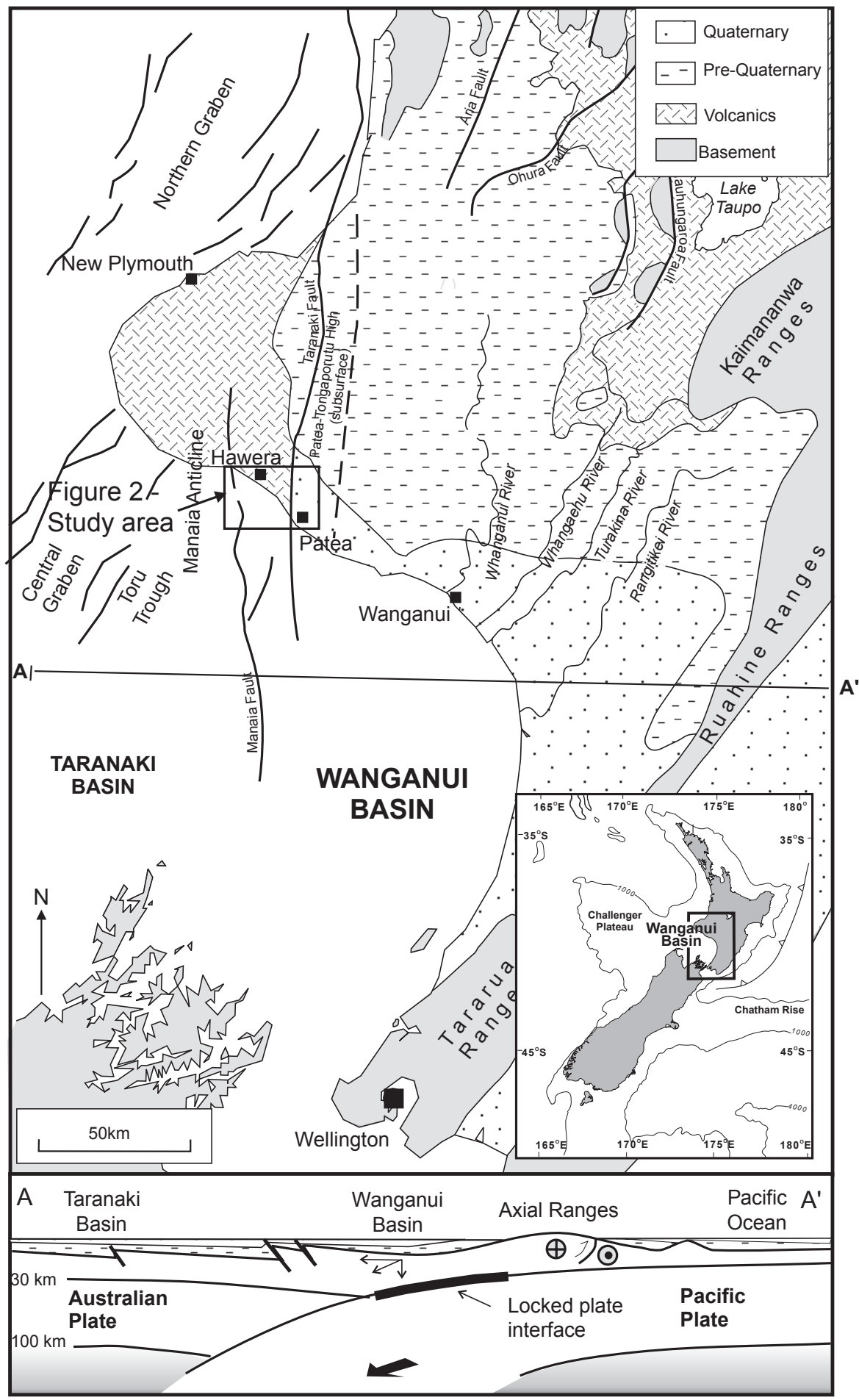

Fig. 1 Location of Wanganui and southern Taranaki Basins in western North Island and their tectonic setting with respect to eastern North Island subduction geometry. The general surface geology of onland regions is shown as well as key physiographic features. 


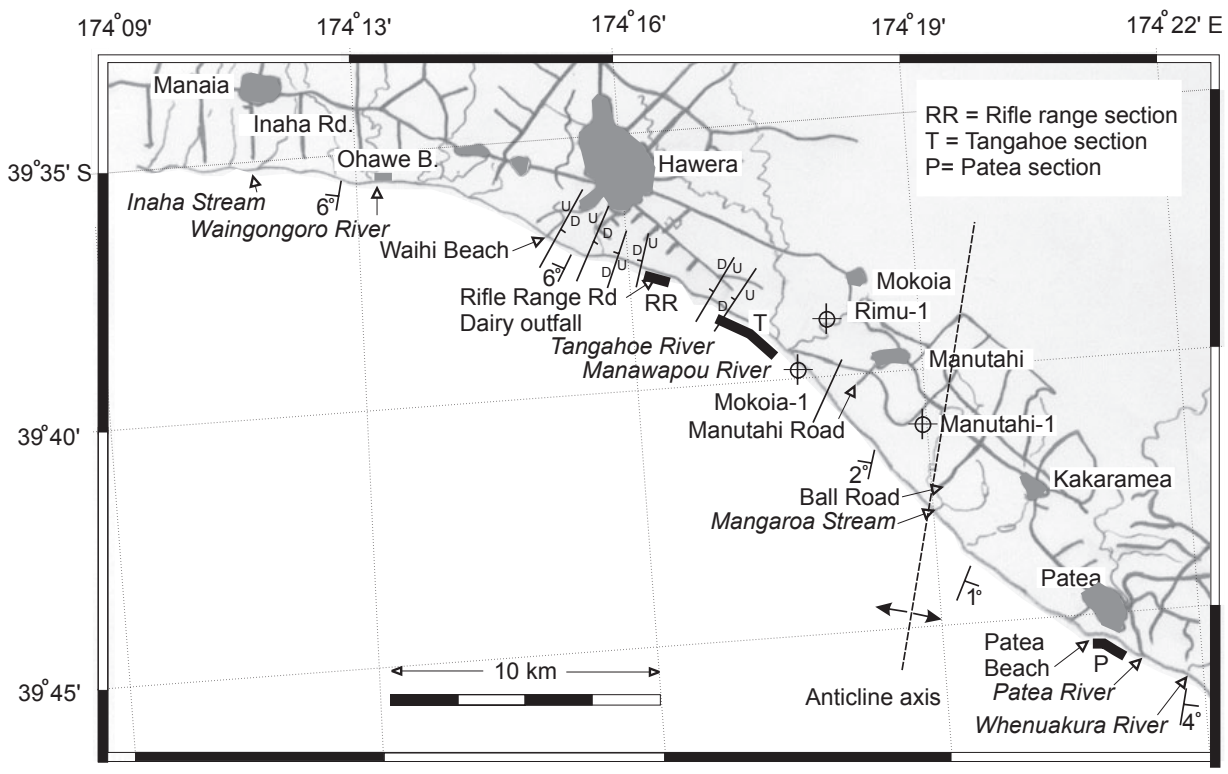

Fig. 2 Map of the coastal section and key geographic features in the study area. Locations of faults and structural information are shown.

margin to "forced regressions" and consider the architecture of Tangahoe Formation forced regressive sandstones in terms of classical models (e.g., Plint 1988) and recent sequence stratigraphic concepts (e.g., Hunt \& Tucker 1992; Posamentier et al. 1992; Naish \& Kamp 1997a).

The development of thick (10-80 m) shelf sequences comprising well developed transgressive, highstand, and regressive systems tracts during 5th order (100 ka) and 6th order (40 ka) glacio-eustatic sea-level cycles is now well established for the late Pliocene and Pleistocene (last c. $2.5 \mathrm{Ma}$ ) fill of Wanganui Basin (Naish et al. 1998; Saul et al. 1999). However, it is intriguing that the $40 \mathrm{ka}$ orbital rhythm also seems to impart a significant control on the cyclothemic character of the Tangahoe Formation and other Early and Middle Pliocene shelf sediments in Wanganui Basin (Kamp et al. 2002; Vonk et al. 2002; this study). This is because major Northern Hemisphere ice sheets, that influenced sea-level change during the last 2.5 m.y., had not yet developed (Shackleton et al. 1984). We address this issue from our palaeobathymetric reconstructions of the sequences and correlations with the marine oxygen isotope record, and we discuss implications for Antarctic ice volume changes.

\section{GEOLOGICAL SETTING}

\section{Basin architecture}

Figure 1 illustrates the behind-arc location of Wanganui Basin in south-western North Island and its relationship to the neighbouring eastern margin of Taranaki Basin. During the PliocenePleistocene, both basins have evolved as one contiguous extensive continental margin. Current interpretations of the broad-scale depositional architecture (Kamp et al. 2002) view the Early Pliocene-Pleistocene fill of both basins as a single 2nd order (5 m.y. duration), northward-prograding continental margin wedge, named the Rangitikei Megasequence. Tangahoe Formation 

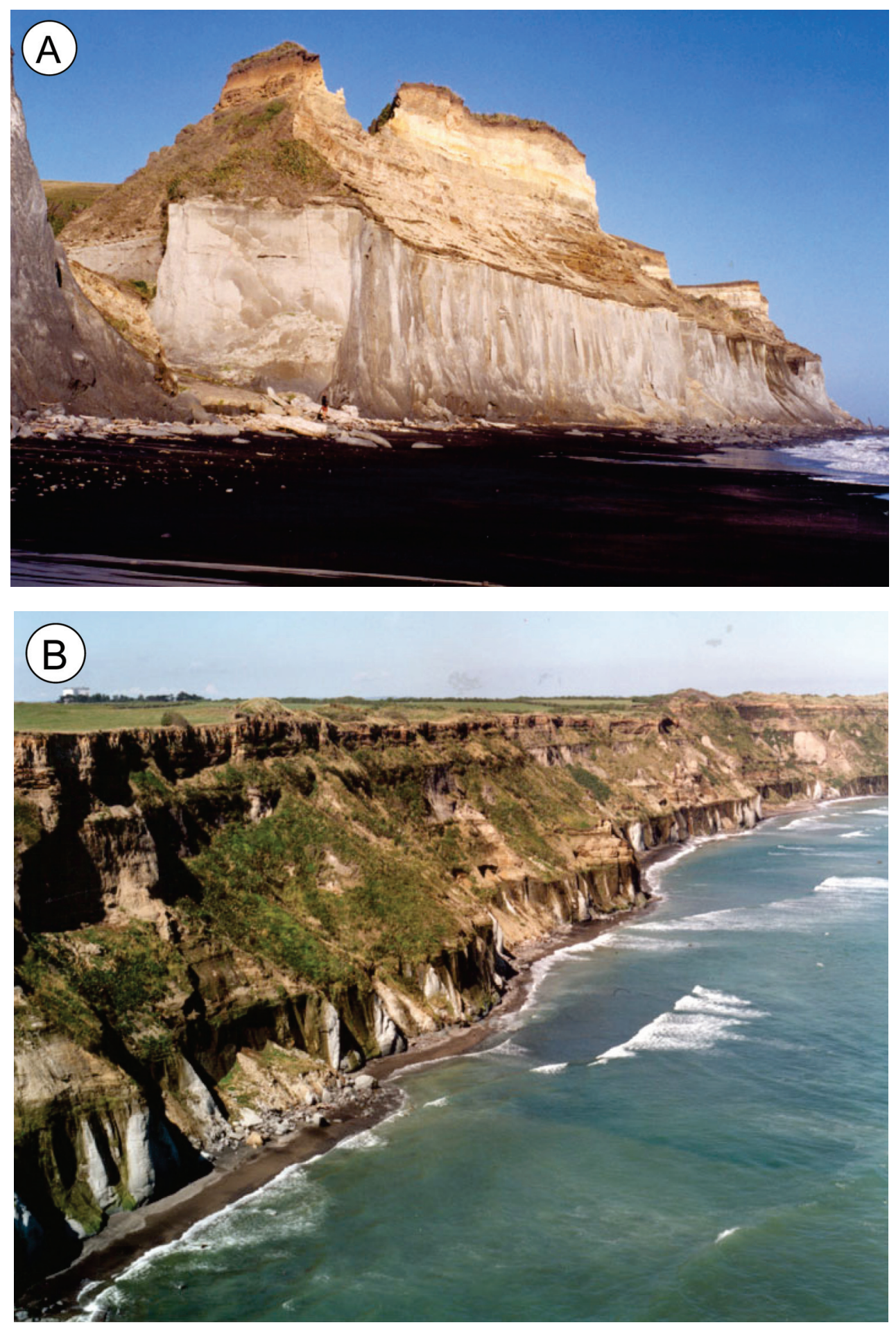

Fig. 3 Representative outcrop photos. A, Ohawe Sandstone at Waihi Beach (Denby Road). Note truncation of the mid-Pliocene strata by the Late Quaternary, Oxygen Isotope Stage 7 (Ngarino) transgressive wave cut surface and overlying terrestrial cover beds. B, General oblique aerial view of the Tangahoe Formation coastal exposure south-east of Manawapou River (Photos: L. Homer). 


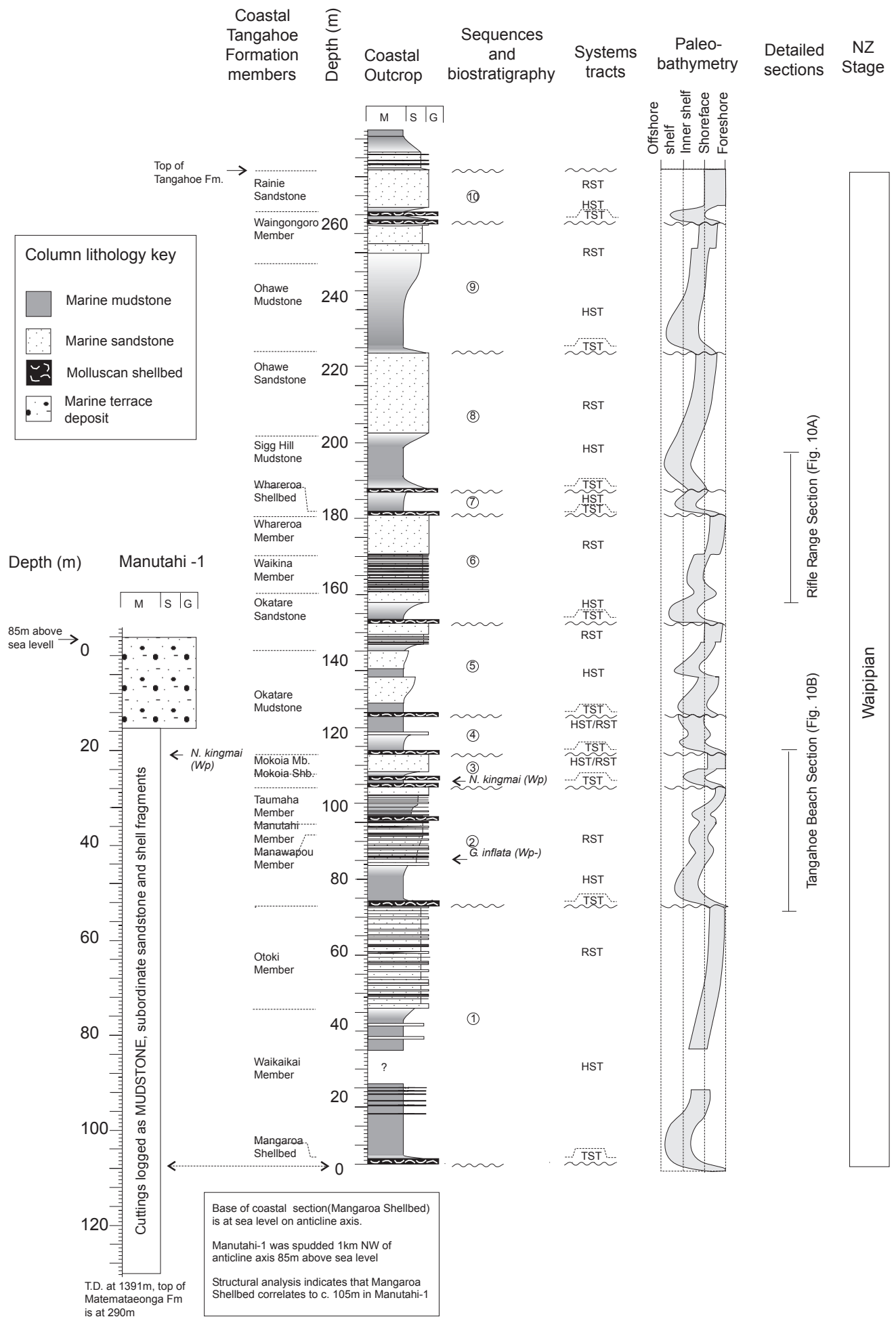


sediments comprise the base of this unit, and represent the infilling of a rapidly subsiding depocentre. The study area is situated on the south-western margin of the mid-Pliocene depocentre and samples the shelf section of the Rangitikei Megasequence. The underlying Matemateaonga Formation comprises the upper shallowest topsets of an older phase of Late Miocene continental margin progradation, known as the Whangamomona Megasequence.

During this, the northern margin of Wanganui Basin experienced regional uplift and tilting of the Wanganui Monocline and the Patea-Tongaporutu basement high as concomitant "pull down" and basin subsidence occurred in the south. The southern margin is defined by a gradually subsiding Mesozoic basement topography north of present day South Island. Progradation of the shelf system also continued west of the Patea-Tongaporutu High, through the Toru Trough into the Central and Northern Grabens of Taranaki Basin and onto the Western Platform, forming the Giant Foresets Formation which underpin the modern shelf and slope.

\section{Stratigraphic subdivision}

The historical classification of sediments in coastal outcrops of southern Taranaki extends back to Mantell (1848), Hochstetter (1864), Buchanan (1870), Hutton (1872), and Park (1887, 1905), who variously used the term Wanganui Beds, Series, Formation, or System to describe "fossiliferous blue-clays" that crop out between Hawera and Patea (summarised in Fleming 1953). Early age assessment, based on fossil content, correlated the Wanganui sediments with the late Tertiary Period. Numerous studies (e.g., Marshall \& Murdock 1920; Marwick 1923, 1924, 1926, 1927; Laws 1941; Beu 1970; Whitten 1973; Beu \& Maxwell 1990) have focused on the spectacular fossil content of the coastal section that comprises the lower half of the stratotype section for the Waipipian Stage (Fleming 1953). The earliest reference to the lithostratigraphy of the coastal section can be traced back to Hay (1967) who applied the name Tangahoe Mudstone to $600 \mathrm{~m}$ of sandy mudstone exposed in the Tangahoe River valley and mapped it eastward into Taranaki Basin. Whitten (1973) recognised the formation in the coastal section and provided the first detailed palaeontologic and stratigraphic assessment of the sediments.

\section{Structure}

In the coastal section, the Tangahoe Formation displays simple post-depositional structure (Fig. 2). The succession is located on the western limb of a gently dipping north-south oriented anticline, where the structural dip of the strata progressively increases upsection and to the west away from the anticline axis from $0-6^{\circ}$. Minor north-south-trending normal faults, with displacements of 5-10 m, offset strata exposed between the Rifle Range section and Waihi Beach (Fig. 2). Fault planes are high angle $\left(70-80^{\circ}\right)$ and downthrow sediments to the east. The majority of the displacement appears to be Quaternary (marine terraces are not disrupted) and may be associated with Late Pliocene tilting of the Patea-Tongaporutu High.

< Fig. 4 Composite stratigraphic column of the mid-Pliocene Tangahoe Formation exposed in coastal cliffs between Mangaroa Stream and Inaha Stream (Fig. 2). Lithostratigraphic names are derived from informal use by Whitten (1973) subsequently emended by Wehland(1999). The lithologic log summarises detailed stratigraphic sections in Fig. 5. Sequence stratigraphic interpretations and palaeobathymetric reconstructions are discussed in the text. Note stratigraphic position of the Tangahoe and Rifle Range sections are described in more detail in Fig. 10A-C. 


\section{SEDIMENTARY LITHOFACIES}

The Tangahoe Formation sequences comprise a wide variety of sedimentary lithofacies that display recurrent vertically stacked successions of facies deposited during recurrent transgressions and regressions of the shoreline across the palaeo-Wanganui/Taranaki shelf and coastal plain.

Eighteen lithofacies have been identified and are grouped into four major lithofacies associations on the basis of sedimentologic (lithology, bedding relationships, sedimentary structures, and texture) and faunal features (macroinvertebrate, trace fossil, and microfossil palaeoecology and taphonomy). Associations are named siltstone, sandstone, heterolithic (siltstone and sandstone), and shellbed after the dominant lithology, and each association corresponds to a broad depth range within an intertidal to middle shelf environmental range. The diagnostic characteristics and interpretation of each facies are drawn from Abbott \& Carter (1994), Naish (1996), Naish \& Kamp (1997a), Kamp \& McIntyre (1998), and Wehland (1999). Facies are described in detail in Appendix 1 and are summarised in Table 1. In some cases, individual facies have been modified from previous studies, new facies defined, and facies codes changed. The vertical occurrences of the facies within the Tangahoe Formation are illustrated in Fig. 5A-C. Representative photographs of facies are shown in Fig. 6A-F.

\section{SEQUENCE STRATIGRAPHY}

Previous sequence stratigraphic analyses (Abbott \& Carter 1994; Naish \& Kamp 1997a; Kamp \& McIntyre 1998; Saul et al. 1999) of the cyclic shallow-marine Pliocene-Pleistocene sediments within Wanganui Basin have utilised the recognition of vertically stacked, cyclic facies successions, bounded by sharp erosional surfaces that mark prominent lithologic dislocations, as the basis for identifying depositional sequences. Facies and biofacies analyses allow interpretation of the spatial and temporal pattern of environmental change within sequences. Accurate interpretation of sequence architecture is greatly aided by an understanding of shellbed types present (summarised in Table 2), and the habitat of their faunas, as first appreciated by Fleming (1953). The post-depositional taphonomic features of the shellbeds have allowed intervals of stratigraphic condensation, due to marine reworking by waves and currents, sedimentary bypassing, or non-deposition, to be identified. Thus, the recognition of (1) vertically-stacked facies successions bounded by sharp erosion surfaces (sequence boundaries), and (2) the distinctive shellbeds and their associated stratal discontinuities, delineate the stratigraphic geometry of the sequences and allow systems tracts to be differentiated (e.g., sensu Vail 1987).

\section{Shellbed nomenclature}

Naish \& Kamp (1997a) and Kondo et al. (1998), after Kidwell (1991), have recognised onlap, backlap, downlap, and flooding surface shellbeds. These shellbeds are associated, respectively, with the transgressive surface of erosion (TSE), a local flooding surface, the downlap surface, and paracycle-bounding marine flooding surfaces. In offshore settings, where the downlap surface converges with the sequence boundary, elements of both onlap and downlap shellbeds may become superposed. For such cases the term "compound shellbed" is useful. Abbott \& Carter (1994) distinguished type A shellbeds within the transgressive systems tract (reworked shallow water species, often cross-bedded); and type B shellbeds (offshore shelf species, preserved in or near situ), which straddle the junction between the transgressive and highstand systems tracts, leading to the term mid-cycle shellbed.

We summarise in Table 2 the nomenclature we have applied in this paper, and its relationship to other shellbed schemes. While the shellbeds discussed herein are given interpretative names, the shellbed types are recognised on the basis of distinctive physical characteristics (composition, taphonomy, sedimentary structures, and stratal relationships; Tables 1 and 2) observed in outcrop. 

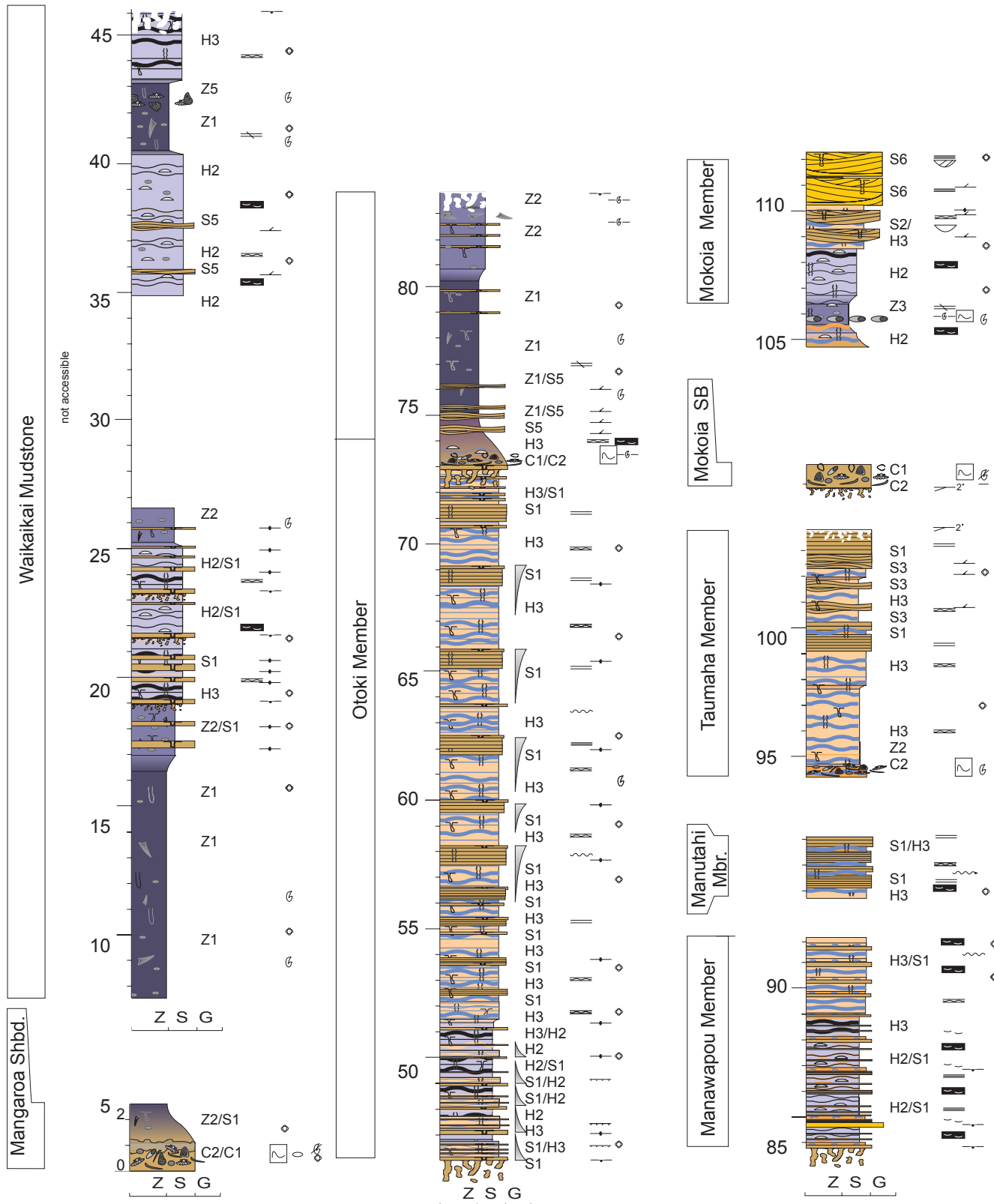

Fig. 5 Detailed stratigraphic logs for each Tangahoe Formation member showing vertical stacking of lithofacies and shellbeds (Table 1). (Continued on next 2 pages) 

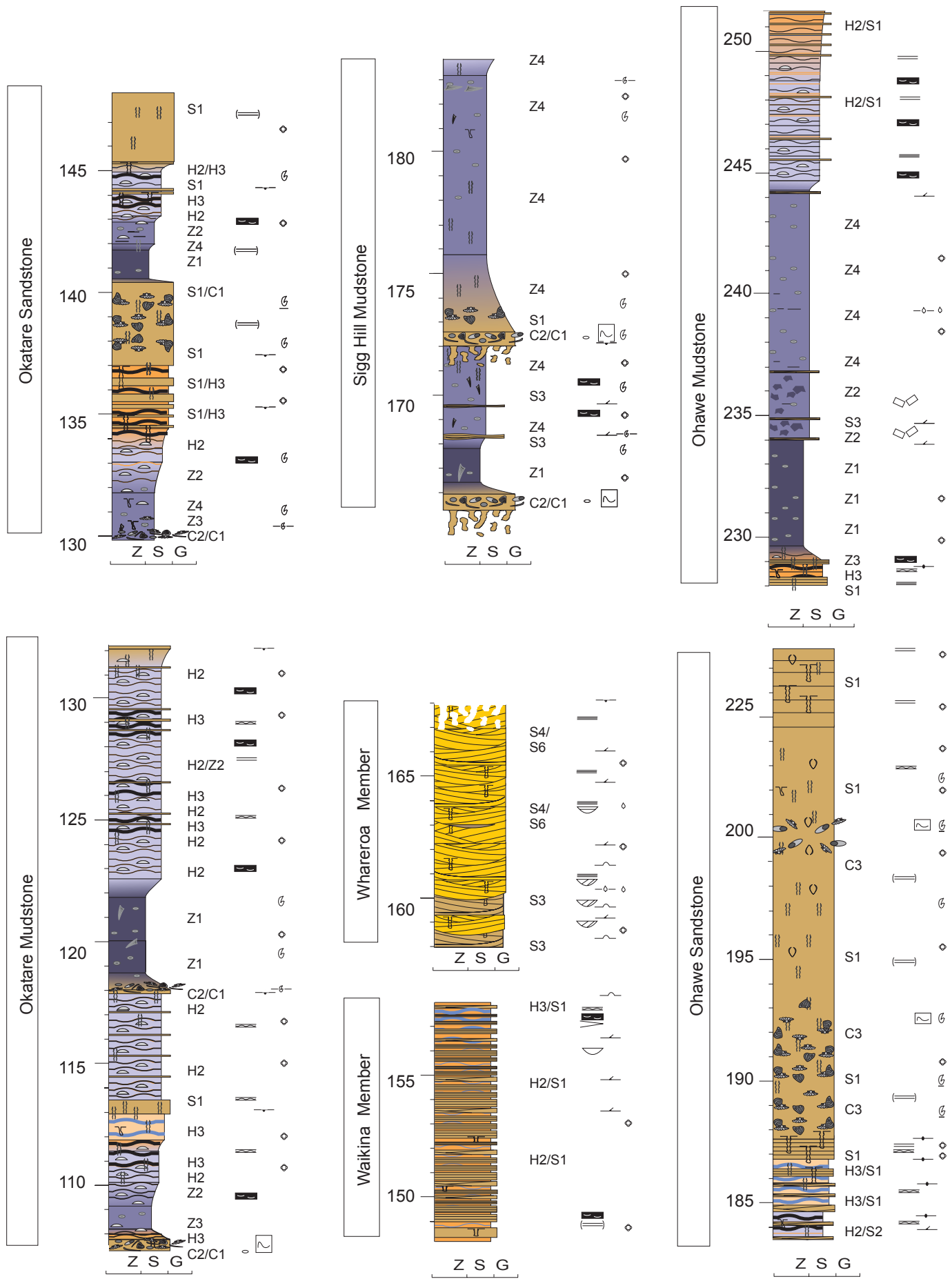

Fig. 5 (continued) 


\section{Facies Key}

\section{Shellbed Association}
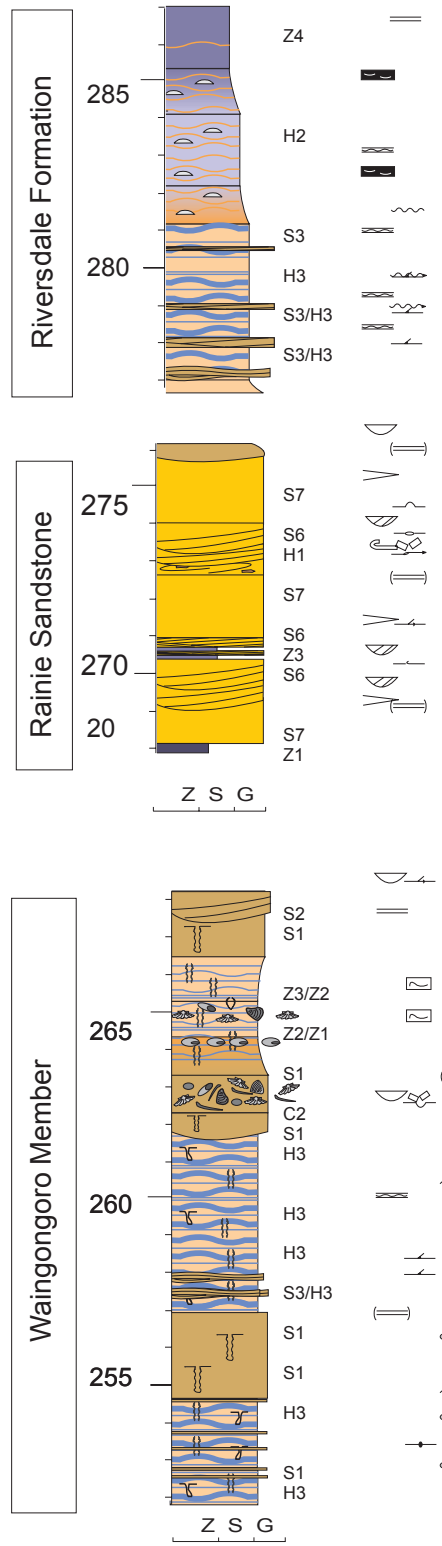

$=\varnothing$

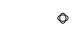

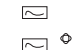

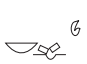

$=\quad$

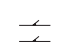

$\Longleftrightarrow$

0
6
${ }^{\circ}$
0
C1

$\mathrm{C} 1 / \mathrm{C} 2$

C2

C3 $\left\{\begin{array}{l}-\infty \\ \infty \infty \infty \\ \infty \infty_{\infty}\end{array}\right.$

\section{Mudstone Association}

Z1
Massive mudstone
Z4
Z4

\section{Heterolithic Association}

$\mathrm{H} 2$

H3
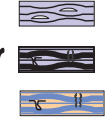

(II)

$=\infty$

$\mathrm{H} 4$

$\mathrm{H}$

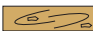

Wavy laminated, lenticular bedded, mudstone

Bioturbated, wavy-bedded, sandy mudstone

Bioturbated, wavy-bedded, muddy sandstone

Wavy-bedded, muddy sandstone

Flaser/ripple-bedded, sandstone

Slumped sandstone with rip-ups

\section{Sandstone Association}
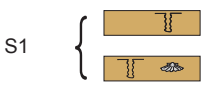

Massive, fine sandstone

Massive, fossiliferous, sandstone

Fine laminated sandstone

S2

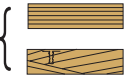

Low-angle to planar cross-stratified sandstone

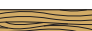

HCS silty to silty fine sandstone

S4

Trough cross-bedded, channelled sandstone

S5

S6

S7

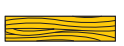

Swaly cross-stratified sandstone

Large scale trough cross-bedded sandstone

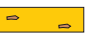

Massive well-sorted sandstone with rip-ups

Fig. 5 (continued) 

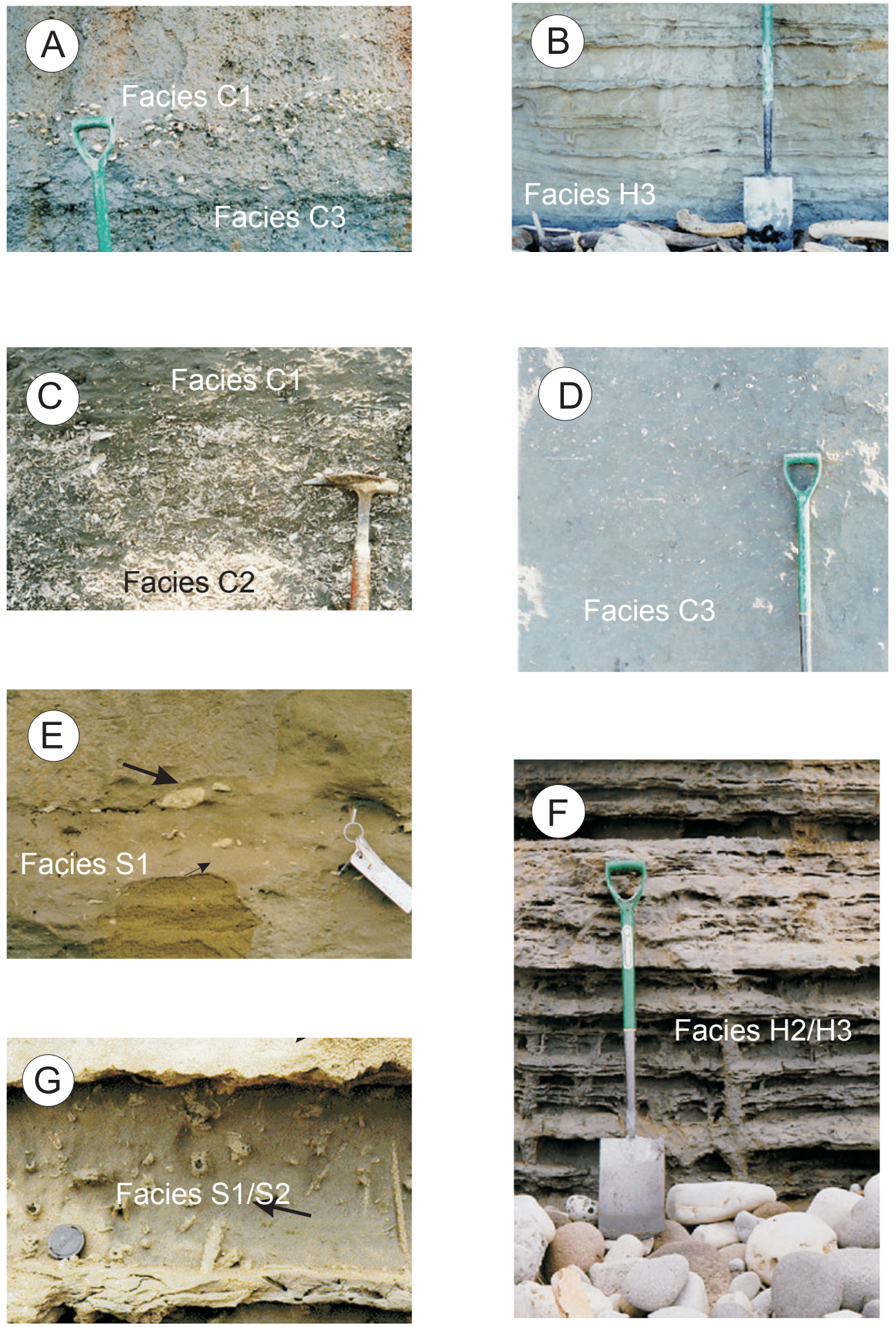

Fig. 6A-G Examples of facies listed in Table 1 and defined in text (Photos: W. Wehland). 


\section{Tangahoe Formation sequence architecture}

Here, we apply a sequence stratigraphic model (described in Appendix 2) to subdivide the mid-Pliocene Tangahoe Formation sediments into stratigraphic sequences representing cycles of relative sea-level change. Ten depositional sequences have been identified in Fig. 4. Each sequence typically contains the following architectural elements in ascending stratigraphic order (sequence stratigraphic terminology used here is summarised Appendix 2).

Table 1 Sedimentary lithofacies of the mid Pliocene Tangahoe Formation coastal outcrop.

\begin{tabular}{|c|c|c|c|}
\hline $\begin{array}{l}\text { Lithofacies } \\
\text { association }\end{array}$ & Code & Description & $\begin{array}{l}\text { Depositional } \\
\text { environment }\end{array}$ \\
\hline \multirow[t]{5}{*}{ Mudstone } & $\mathrm{Z1}$ & $\begin{array}{l}\text { Blue-grey, unweathered, sparsely to moderately } \\
\text { fossiliferous, massive, bioturbated mudstone }\end{array}$ & Shelf \\
\hline & $\mathrm{Z} 2$ & $\begin{array}{l}\text { Blue-grey, unweathered, wavy to streaky-laminated/ } \\
\text { bedded sandy mudstone }\end{array}$ & Inner shelf \\
\hline & $\mathrm{Z} 3$ & Blue-grey, brecciated mudstone & Inner shelf \\
\hline & $\mathrm{Z} 4$ & $\begin{array}{l}\text { Blue-grey, massive, bioturbated, moderately } \\
\text { fossiliferous sandy mudstone }\end{array}$ & Inner shelf \\
\hline & $\mathrm{Z} 5$ & Grey, laminated sandy mudstone & Inner shelf \\
\hline \multirow[t]{4}{*}{ Heterolithic } & H1 & $\begin{array}{l}\text { Slumped, soft sediment deformed sandstone with } \\
\text { intraclasts }\end{array}$ & Shoreface \\
\hline & $\mathrm{H} 2$ & $\begin{array}{l}\text { Blue-grey, unweathered, wavy and lenticular bedded/ } \\
\text { laminated sandy mudstone }\end{array}$ & Intertidal lagoon \\
\hline & H3 & $\begin{array}{l}\text { Grey, unweathered, wavy bedded/laminated } \\
\text { sandstone/mudstone }\end{array}$ & Intertidal lagoon \\
\hline & $\mathrm{H} 4$ & $\begin{array}{l}\text { Brown-grey, flaser/rippled-bedded/laminated } \\
\text { sandstone }\end{array}$ & Intertidal lagoon \\
\hline \multirow[t]{7}{*}{ Sandstone } & S1 & $\begin{array}{l}\text { Brown-grey, moderately weathered, unconsolidated, } \\
\text { sparsely fossiliferous, bioturbated, massive well } \\
\text { sorted fine sandstone }\end{array}$ & Shoreface \\
\hline & S2 & $\begin{array}{l}\text { Brown-grey, moderately weathered, unconsolidated, } \\
\text { sparsely fossiliferous, bioturbated, low angle planar } \\
\text { to horizontally laminated well sorted fine sandstone }\end{array}$ & Foreshore/beach \\
\hline & S3 & $\begin{array}{l}\text { Grey, unweathered, barren, hummocky cross- } \\
\text { stratified silty fine sandstone }\end{array}$ & Innermost shelf \\
\hline & S4 & $\begin{array}{l}\text { Brown-grey, moderately weathered, channel-fill } \\
\text { trough cross-stratified sandstone }\end{array}$ & $\begin{array}{l}\text { Lower to mid } \\
\text { shoreface }\end{array}$ \\
\hline & S5 & $\begin{array}{l}\text { Grey, unweathered, barren, swaley cross-stratified } \\
\text { sandstone }\end{array}$ & Lower shoreface \\
\hline & S6 & $\begin{array}{l}\text { Brown-grey, moderately weathered, large scale trough } \\
\text { cross-stratified sandstone }\end{array}$ & Innermost shelf \\
\hline & S7 & Brown, well sorted, ripple cross-stratified sandstone & Beach \\
\hline \multirow[t]{3}{*}{ Shellbed } & $\mathrm{C} 1$ & $\begin{array}{l}\text { Closely packed molluscan shells within bioturbated } \\
\text { terrigenous sandstone or siltstone; shells are in situ or } \\
\text { only weakly transported }\end{array}$ & Inner to mid shelf \\
\hline & $\mathrm{C} 2$ & $\begin{array}{l}\text { Closely packed, shell pebble conglomerate or pebbly } \\
\text { sandstone; includes old and new abraded molluscs, } \\
\text { intraclasts, greywacke pebbles within a coarse sand } \\
\text { matrix; may also include mud drapes }\end{array}$ & Shoreface \\
\hline & $\mathrm{C} 3$ & $\begin{array}{l}\text { Bands, clumps and scattered, often monospecific in } \\
\text { situ molluscs within bioturbated massive siltstone to } \\
\text { fine sandy siltstone and sandstone }\end{array}$ & Inner to mid shelf \\
\hline
\end{tabular}


Table 2 Genetic classification of Wanganui Basin shellbeds (after Naish \& Kamp 1997a).

\begin{tabular}{|c|c|c|c|c|}
\hline Shellbed type & $\begin{array}{l}\text { Litho- } \\
\text { facies } \\
\text { code }\end{array}$ & Description & $\begin{array}{l}\text { Depositional } \\
\text { environment }\end{array}$ & $\begin{array}{l}\text { Sedimentary } \\
\text { dynamics }\end{array}$ \\
\hline $\begin{array}{l}\text { Onlap (1) } \\
\text { (K Type 4, } \\
\text { A\&C Type A) }\end{array}$ & $\mathrm{C} 2$ & $\begin{array}{l}\text { Closely packed, cross- } \\
\text { stratified shell pebble } \\
\text { conglomerate or pebbly } \\
\text { sandstone; medium } \\
\text { to coarse sand matrix. } \\
\text { Basal palimpsest and } \\
\text { or reworked shellbed } \\
\text { decreases shelliness } \\
\text { upwards. }\end{array}$ & $\begin{array}{l}\text { Innermost shelf } \\
\text { to shoreface/ } \\
\text { subtidal or } \\
\text { intertidal } \\
\text { channel or delta }\end{array}$ & $\begin{array}{l}\text { Current and wave } \\
\text { winnowing of fines, } \\
\text { sedimentary bypassing } \\
\text { and erosion during } \\
\text { marine onlap }\end{array}$ \\
\hline $\begin{array}{l}\text { Onlap (2) } \\
\text { (K Type } 3 \& 4, \\
\text { A\&C Type A) }\end{array}$ & $\mathrm{C} 1$ & $\begin{array}{l}\text { Closely packed to } \\
\text { loosely packed, } \\
\text { molluscan shells within } \\
\text { gritty silty sandstone } \\
\text { and sandstone }\end{array}$ & $\begin{array}{l}\text { Inner shelf to } \\
\text { shoreface }\end{array}$ & $\begin{array}{l}\text { Sediment starvation } \\
\text { and bypassing during } \\
\text { marine onlap }\end{array}$ \\
\hline $\begin{array}{l}\text { Backlap } \\
\text { (K Type 1, } \\
\text { A\&C Type B) }\end{array}$ & $\mathrm{C} 1$ & $\begin{array}{l}\text { Loosely packed } \\
\text { to closely packed, } \\
\text { molluscan shells } \\
\text { within gritty, fine } \\
\text { sandy siltstone. Shell } \\
\text { concentration and } \\
\text { relative abundance } \\
\text { of epifauna increases } \\
\text { upwards. }\end{array}$ & $\begin{array}{l}\text { Inner shelf to } \\
\text { middle shelf }\end{array}$ & $\begin{array}{l}\text { Sediment starvation } \\
\text { and bypassing during } \\
\text { marine onlap, with } \\
\text { abundant suspended } \\
\text { food resources. } \\
\text { Bypassing of sediment } \\
\text { promotes a stable } \\
\text { shellground substrate. }\end{array}$ \\
\hline
\end{tabular}

$\begin{array}{llll}\begin{array}{l}\text { Downlap } \\ \text { (K Type 3) }\end{array} & \text { C3 } & \begin{array}{l}\text { Loosely packed to } \\ \text { clumped and in situ } \\ \text { molluscan shells within } \\ \text { gritty, fine sandy fine } \\ \text { siltstone }\end{array} & \begin{array}{l}\text { Inner shelf to } \\ \text { middle shelf }\end{array} \\ & \end{array}$

Marine flooding $\mathrm{C} 1 / \mathrm{C} 3$ Loosely packed Inner shelf surface to closely packed, (K Type 3) molluscan shells within gritty, fine sandy siltstone to fine siltstone

Moderate rates of finegrained sediment supply promotes an unstable substrate in the distal part of the nearshore sediment wedge

Sediment starvation and bypassing during marine onlap

Compound = Onlap and backlap shellbeds superposed. 


\begin{tabular}{|c|c|c|c|}
\hline Palaeocommunity & $\begin{array}{l}\text { Palaeocommunity } \\
\text { characteristics }\end{array}$ & Taphonomy & Stratal relationship \\
\hline $\begin{array}{l}\text { Sandy shoreface: } \\
\text { Zethalia, Fellaster, } \\
\text { Paphies, Myadora, } \\
\text { Dosinia, Austrovenus } \\
\text { Muddy estuary: } \\
\text { Cyclomactra, } \\
\text { Barnea, Xymene, } \\
\text { Maoricolpus, Tawera }\end{array}$ & $\begin{array}{l}\text { Dominated by } \\
\text { infaunal detritus } \\
\text { feeding molluscan } \\
\text { species; low to } \\
\text { moderate diversity }\end{array}$ & $\begin{array}{l}\text { Poorly to } \\
\text { moderately } \\
\text { preserved broken } \\
\text { and abraded } \\
\text { shells }\end{array}$ & $\begin{array}{l}\text { Shallow water wave } \\
\text { and/or current influenced } \\
\text { deposition associated with } \\
\text { the development of the } \\
\text { ravinement and marine } \\
\text { flooding surfaces within the } \\
\text { TST. Overlies RS at base } \\
\text { of TST and grades up into } \\
\text { shallow water terrigenous } \\
\text { TST facies. }\end{array}$ \\
\hline
\end{tabular}

Sandy nearshore/inner shelf: Scalpomactra, Gari, Divaricella, Lutraria, Panopea

Dominated by infaunal detritus feeding molluscan species; moderate diversity
Shelf shellground:

Puropurcardia, Tawera, Maoriculpus, Chlamys,

Limaria, Tisotrea, Glycymerula, Tucetona, Barbatia, Neothyris

Shelf mud: Chlamys, Nemocardium, Serratina, Neilo, Echinocardium, Turrid spp., Zenatia, Antalis

Sandy shoreface, sandy nearshore/inner shelf, or shelf mud palaeocommunities
Diverse, mixed benthos dominated by suspension-feeding bivalves, although brachiopods occur. Members are shallow burrows or epifaunal. Encrusting bryozoa and barnacles are common.

Moderately diverse, dominated by detritus feeding species. Carnivorous gastropods are common.

Restricted to diverse, mixed infaunal to epifaunal benthos
Moderately to well preserved near and in situ, articulated and disarticulated molluscan shells

Moderately to well preserved near and in situ, articulated and disarticulated molluscan shells may be encrusted and bored

Well preserved in situ, articulated molluscan shells

Typically abraded and/or disarticulated reworked and near situ molluscan fauna
Shallow water deposit below fair weather wave base associated with the development of the ravinement and marine flooding surfaces within the TST. Overlies RS at base of TST and grades up into shallow water terrigenous TST facies.

Offshore shelf deposit associated with nearshore trapping of terrigenous sediment during transgression and highstand. Capped by downlap surface and HST terrigenous mudstone. Lower contact gradational or marked by a burrowed marine flooding surface.

Offshore shelfal deposit associated with initial progradation of fine grained terrigenous sediment during highstand. Located in the lower part of the HST above the DLS.

Associated with marine flooding surface within TST, HST, and/or RST, and concentrated by sediment bypassing during marine onlap 


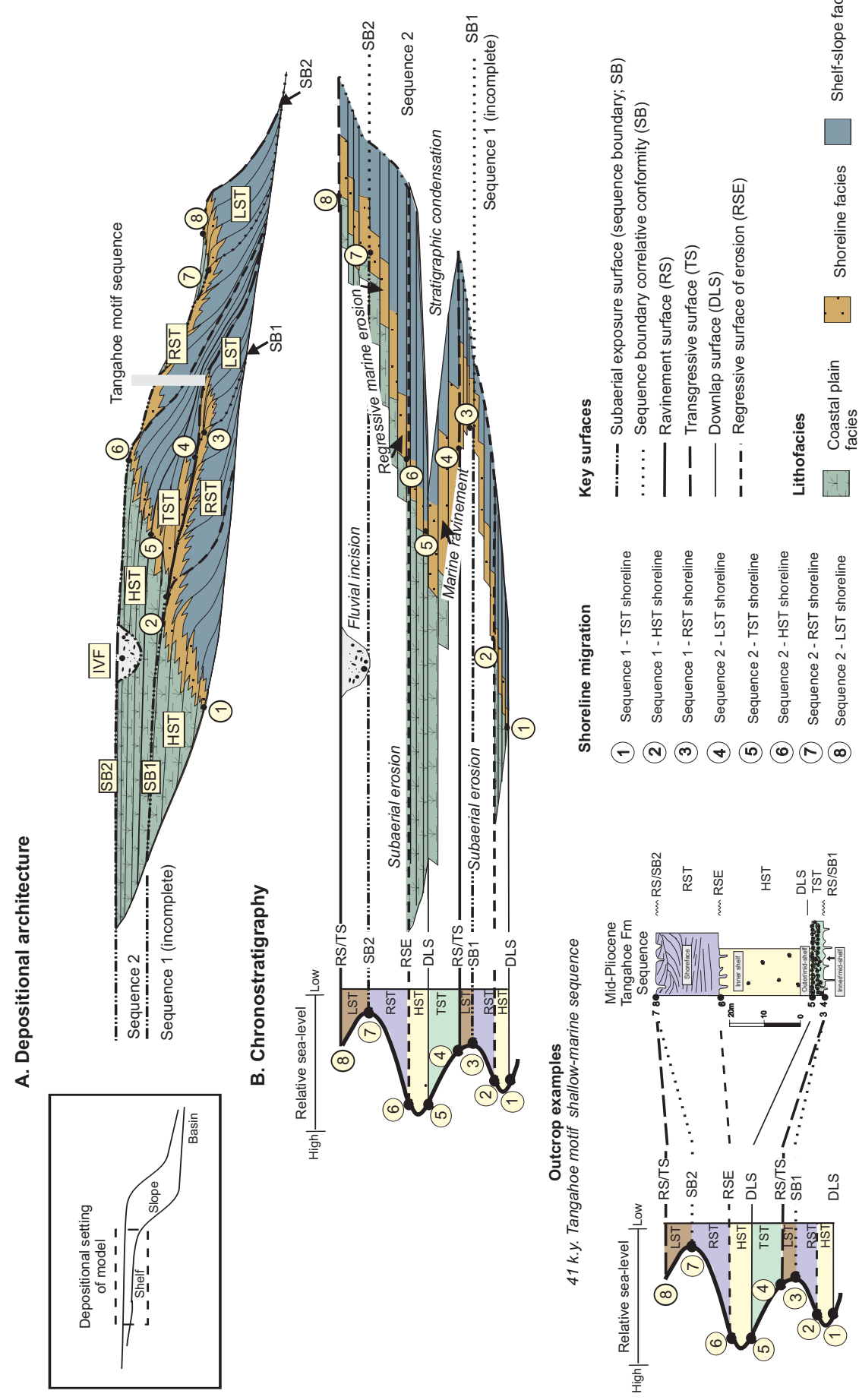

Fig. 7 Conceptual sequence stratigraphic model for 5 th and 6 th order deposition sequences in Wanganui Basin. A, Depositional architecture during 1.5 cycles of relative change in sea level. B, Chronostratigraphy highlights zones of stratigraphic condensation and erosion. A typical sequence motif is shown for the Tangahoe Formation. 
Figure 7 illustrates the conceptual sequence stratigraphic model, and Fig. 8 shows photographic examples of key surfaces and systems tracts.

(1) A basal sequence boundary (SB) consisting of an unconformity, which is coincident with the transgressive surface of erosion (TSE) (Fig. 8E).

(2) A thin $(<2 \mathrm{~m})$ transgressive systems tract (TST), corresponding mainly to a condensed fossiliferous deepening-upwards interval comprising shellbed facies $\mathrm{C} 1$ and/or $\mathrm{C} 2$. This unit comprises an onlap shellbed (Table 2) containing shallow water infaunal molluscs (sandy $\mathrm{C} 1$ and sometimes reworked C2), and is overlain by a backlap shellbed (Table 2) comprising significantly more in situ epifaunal components (molluscs, barnacles, brachiopods, and bryozoans) within a siltstone matrix of offshore shelf affinity. These superposed or vertically gradational shellbed units are termed compound shellbeds (Fig. 8A,E; Table 2).

(3) A downlap surface (DLS; Fig. 8E).

(4) A highstand systems tract (HST) $(5-40 \mathrm{~m})$ comprising an aggradational interval of bioturbated shelf siltstone (Z1-Z4) (Fig. 8).

(5) A regressive systems tract (RST) (5-40 m) above a regressive surface of erosion (RSE) (Fig. 8B,C), that dislocates fine sandy siltstone facies (S3) and/or hummocky cross-stratified sandstone (S4) of inner shelf affinity in the upper HST from a strongly progradational, detached "forced regressive" shoreface-foreshore facies assemblage (S5-S7 and S1-S2) (Fig. 8A). In some sequences, the transition from inner shelf mudstone to shoreline sandstone is abrupt with no significant erosion and basinward disjunction of the shore connected sand wedge.

\section{PALAEOBATHYMETRY}

A stratigraphically intermittent dataset obtained during this study on the foraminiferal content of the shallow-marine sequences of the coastal Tangahoe Formation have been combined with macrofaunal data from previous studies (Whitten 1973; Beu \& Maxwell 1990) in an attempt to provide additional constraints for a palaeobathymetry curve for the coastal section (Fig. 4). In the previous text we have integrated lithofacies analysis and sequence stratigraphy to identify genetic packages of sediment, or systems tracts, deposited during particular phases of a relative sea-level cycle from which broad inferences can be drawn regarding palaeoenvironmental and palaeowater-depth changes within and between sequences. Here, we use a qualitative assessment of the foraminiferal and macrofaunal dataset to help reconstruct palaeobathymetry. Water depth changes within shallow water sandy facies and offshore shelfal facies of $\pm 5-10 \mathrm{~m}$ and \pm 25 m, respectively, are typically resolved (Abbott 1997; Abbott \& Carter 1997; Naish \& Kamp 1997b; Kamp et al. 1998).

\section{Foraminiferal depth palaeoecology}

Samples were collected and processed according to the procedures outlined in Naish \& Kamp (1997b) and the standard procedures used by the Institute of Geological and Nuclear Sciences in foraminiferal census studies. Forty-six samples were processed from representative sedimentary facies within the Tangahoe Formation coastal section. Of these, only 16 yielded useful faunas and in sufficient numbers to enable identification of depth-related associations. The majority of barren samples were from sandy facies for which sedimentological information provides some depth control. Nevertheless, three benthic biofacies have been identified from the census data (available from http://data.gns.cri.nz/), which are compared with Recent foraminiferal palaeoenvironmental data (Hayward et al. 1999) and Pliocene-Pleistocene foraminiferal palaeobathymetry (Haywick \& Henderson 1991; Abbott 1997; Naish \& Kamp 1997b; Kamp et al. 1998). Figure 9 summarises spatial distribution of common extant foraminifera on the New Zealand continental shelf and slope. 

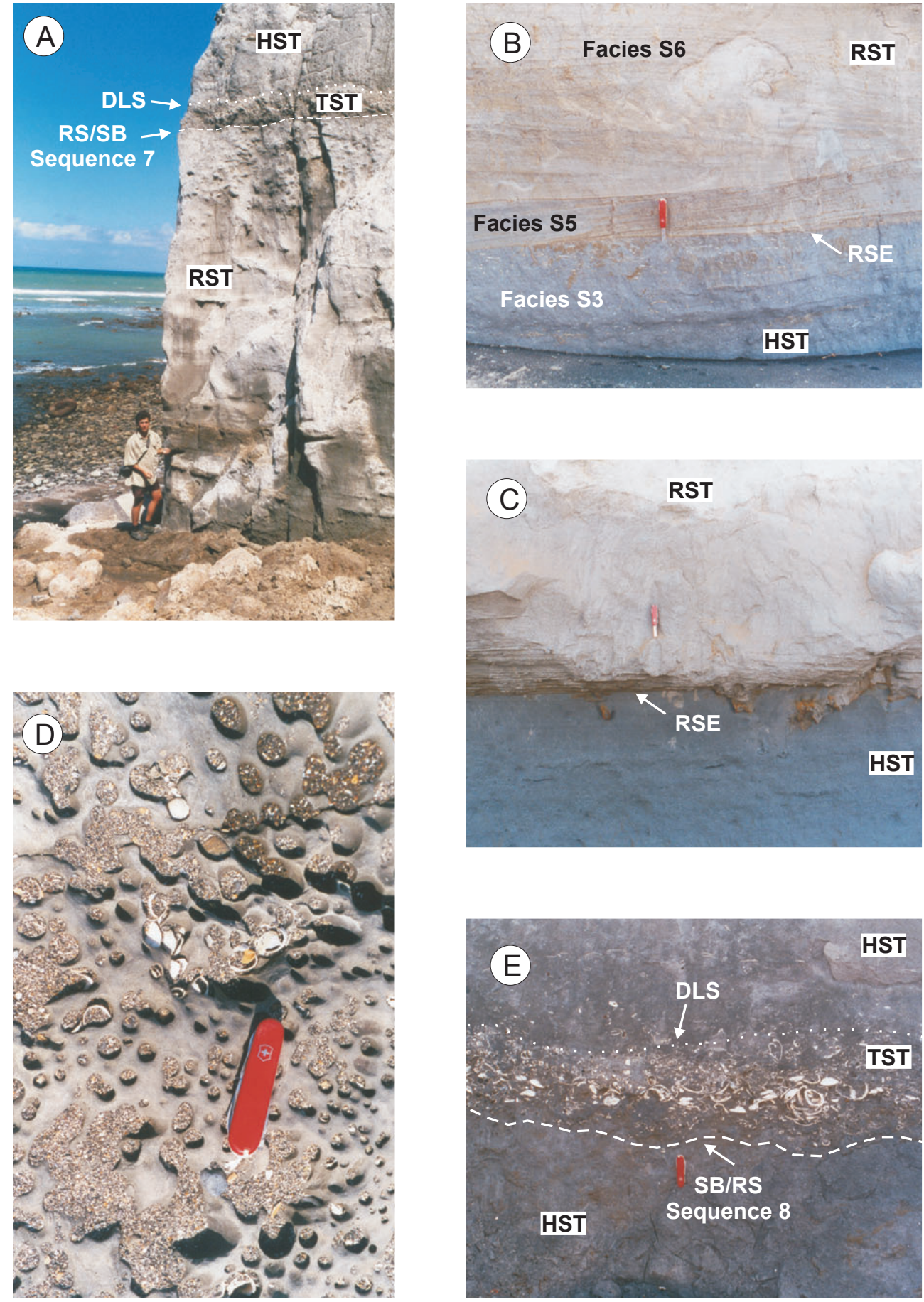

Fig. 8A-E Facies transitions and key sequence stratigraphic surfaces discussed in text (Photos: T. Naish). 


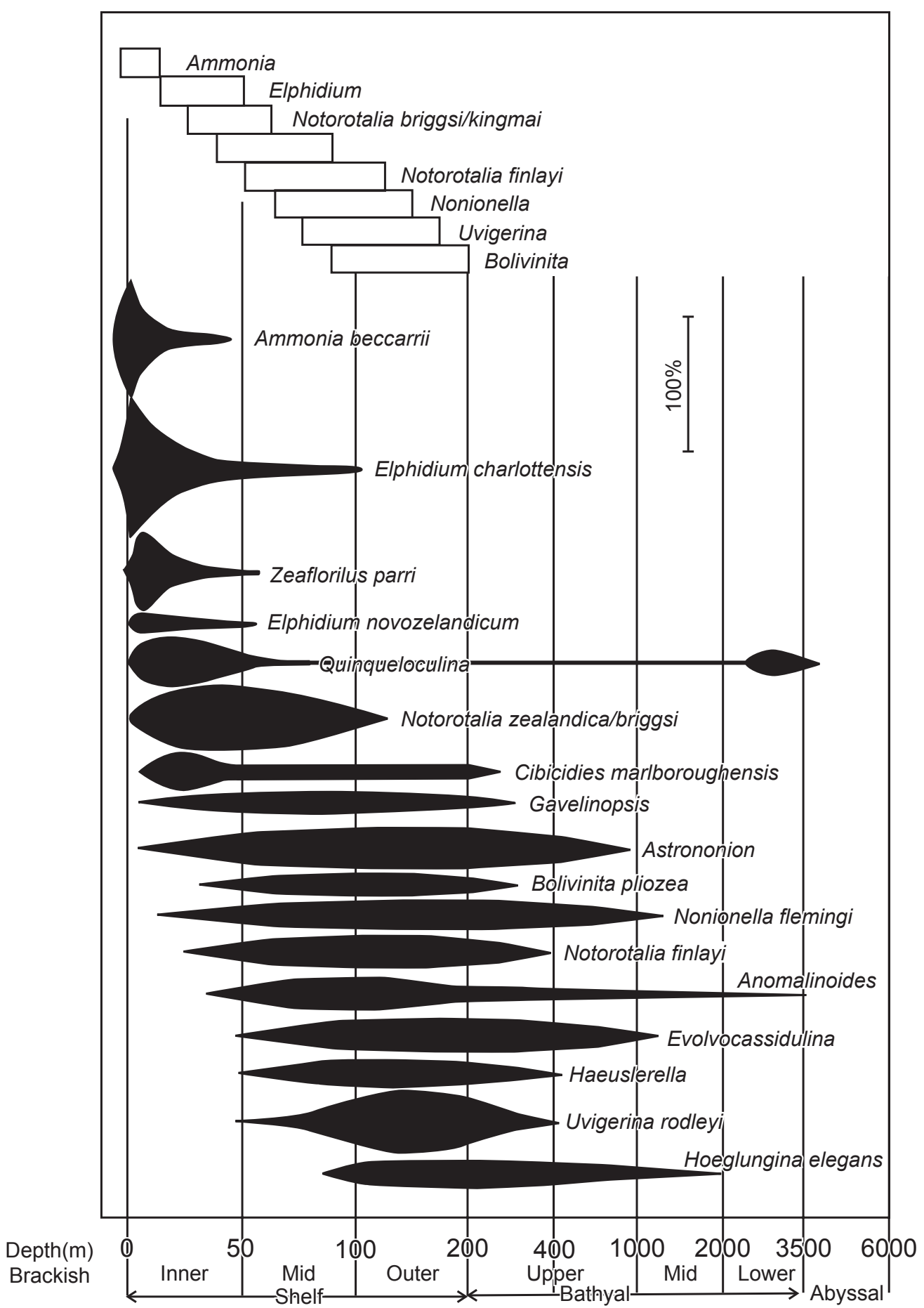

Fig. 9 The depth ranges of benthic foraminifera on the New Zealand shelf and oceanic margin (after Hayward 1986). Also shown are foraminiferal depth related biofacies based on other Pliocene-Pleistocene studies of foraminiferal depth palaeoecology by Haywick \& Henderson (1991), Naish \& Kamp (1997b), Abbott (1997), and Kamp et al. (1998). 


\section{Nonionellina biofacies}

This is the most common association in bioturbated shelf mudstone facies and is dominated by Nonionellina flemingi (48\%) with subordinate species including Astrononion parki (16.5\%), Notorotalia finlayi (14.3\%), Elphidium charlottense (6.8\%), Evolvocassidulina orientalis (4.7\%), and Bulimina marginata (4.4\%). The Nonionellina biofacies compares well with: (1) Association N, Nonionellina flemingi, 30 m (mid-outer shelf, Hayward et al. 1999); (2) Association E, Nonionella (inner-mid shelf, Haywick \& Henderson 1991); and (3) Association J, Nonionella (mid-outer shelf, Naish \& Kamp 1997b). It is also somewhat comparable with cluster 7 associations (mid-outer shelf) of Kamp et al. (1998) and could be placed within Associations E and F (inner shelf, $50 \mathrm{~m}$ ) of Abbott (1997). We place the Nonionellina biofacies at a palaeodepth inner/mid shelf-outer shelf between 25-100 m. Samples containing Nonionella biofacies span siltstone facies Z1-Z4.

Notorotalia kingmai biofacies

This biofacies is of similar faunal composition to the Nonionellina biofacies, but with considerably less $N$. flemingi (7.3\%) and abundant Notorotalia kingmai (28.4\%) and Astrononion parki (26.6\%). The Notorotalia kingmai/pliozea group becomes extinct in the Mangapanian where it is replaced by $N$. zelandica, and thus has no palaeobathymetric record in the Late Pliocene-Recent studies. Hayward (1986) considers that $N$. kingmai ranged across the shelf, but as it was replaced by $N$. zelandica/briggsi we assume here that it had a similar ecology. In the Recent, $N$. zelandica is most common in open, sandy inner shelf locations. Fossil records also place it on the inner shelf (Haywick \& Henderson 1991). The association of this biofacies with sandy shellbed facies $\mathrm{C} 1$ is consistent with an inner shelf water depth of 10-25 m, but not innermost shelf, as it lacks other key shallow, nearshore taxa.

\section{Zeaflorilus biofacies}

The biofacies is dominated by Zeaflorilus parri (17.5\%) and Nonionellina flemingi (18\%), with subdominants Astrononion parki (13.2\%), Notorotalia finalyi (6.3\%), Elphidium charlotense (5.8\%), Lenticulina spp. (5.8\%), and Anomalinoides parvumbilia (5.3\%). Vella (1962) placed the Pseudonion (= Zeaflorilus) biofacies in the sublittoral zone $(<4 \mathrm{~m})$, and mainly in well sorted sandstone. Hayward (1986) has abundant Zeaflorilus parri occupying innermost shelf depths with turbulent water conditions. Hayward et al. (1999) placed Z. parri in Association Z (mean depth $8 \mathrm{~m}$ ) and considered $Z$. parri to be widespread and abundant in exposed shallow, coarse sediments, usually shallower than $25 \mathrm{~m}$. This biofacies is consistent with Association C of Naish \& Kamp (1997b) and Association A of Haywick \& Henderson (1991), with assigned palaeodepths of 10-50 and 0-10 $\mathrm{m}$, respectively.

The absence of restricted shallower water taxa, such as Ammonia sp., relatively low abundances of Elphidium spp., and the co-dominance of Nonionellina flemingi indicate that the Zeaflorilus biofacies represents the deeper end of the above range, perhaps 10-25 $\mathrm{m}$. Such a palaeodepth interpretation is supported by the dominance in this facies of hummocky and swaly cross-stratified facies S3 and S5, and bioturbated sandy mudstone facies Z4 of inner and innermost shelf affinity between fair weather and storm wave base.

\section{Molluscan depth palaeoecology}

We have used a previous study of the molluscan palaeontology of the coastal section of the Tangahoe Formation by Whitten (1973), together with qualitative assessments of molluscan taxa made during the present study, to support our palaeobathymetric interpretations for the sequences. Mollusc-derived palaeodepth ranges are generally based on the distribution of extant fossil associations or communities on the modern coastline and continental shelf 
(Morton \& Miller 1968; McKnight 1969; Gillespie 1992). Our calibration of depth ranges of molluscan taxa also draws on the depth-related associations reported by Abbott \& Carter (1997) for the Pleistocene sequences of the Castlecliffian stratotype section, as well as ranges reported by Beu \& Maxwell (1990) and references therein. Like foraminifera, sporadic occurrence of macrofauna across the range of facies described for the Tangahoe Formation sequences limits their utility in water depth assessment. However, the associations identified below augment both our sedimentologic and foraminiferal palaeodepth interpretations. The following depth-related associations were described by Whitten (1973), and have been used with modification in this study.

(1) Dosinia lambata, Pteromyrtea dispar, Divaricella hottoniana with subordinate Nemocardium pulchellum, Scalpomactra scalpellum, Gari lineolata, Maoricolpus roseus, and Amalda sp. Dominant epifaunal elements include the ubiquitous Chlamys gemmulata, the Waipipian index pectenids Phialopecten triphooki marwicki and Mesopeplum crawfordi, and Tiostrea lutraria. Depth diagnostic components of this association include: Dosinia lambata found on the inner shelf $(<30 \mathrm{~m})$ in fine sandy muds (McKnight 1969; Beu \& Maxwell 1990); and Gari lineolata and Scalpomactra scalpellum, which together with Myodora striata, are characteristic inhabitants of shallow water inner shelf-innermost shelf environments off sandy beaches. This association is comparable to the inner shelf Gari association of Abbott \& Carter (1997), but also comprises components of their offshore Serratina mud community. Within sequences of the Tangahoe Formation the association occurs in sandy mudstone facies Z2 and Z4 and fine sandstone facies S1. Examples include the Waikaikai Mudstone and upper portions of the Ohawe Mudstone.

(2) Maoricolpus roseus, Atrina zelandica, Dosinia zelandica with subordinate Polinices waipipiensis, Pteromyrtea dispar, Chlamys gemmulata, Mesopeplum crawfordi, Lima waipipiensis, and Tiostrea lutaria. This association was assigned to innermost shelf-sandy shoreface environments by Whitten (1973), who noted many similarities with Powell's (1937) Maoricolpus-Dosinia-Paphirus Auckland Harbour community. The components of this association typically occur in sandy shoreface facies S1 in the Tangahoe sequences (e.g., Ohawe Sandstone), and it is a mixture of Abbott \& Carter's (1997) Paphies and Gari associations.

(3) Glycymeris manaiaesis, Marama murdochi with subordinate components Nemocardium pulchellum, Panopea wanganuica, Polinices waipipiensis, Mesopeplum crawfordi, and Crepidula radiata. The presence of Marama murdochi, which lives on the mid-outer shelf (Beu \& Maxwell 1990), and the similarity of the association to the offshore Serratina mud community of Abbott \& Carter (1997), support the occurrence of this association in mudstone facies and our interpretation of a mid shelf depositional environment. Lower parts of the Ohawe Mudstone and the Waingongoro Formation contain examples of this association.

\section{Palaeobathymetry curve}

The foraminiferal and molluscan associations described above allow palaeobathymetric constraints to be placed on most of the facies recognised within the Tangahoe Formation sequences. In shallow sandy facies, where carbonate faunal components are rare, sedimentary structures, such as hummocky cross-stratification, symmetrical wave ripples, flaser bedding and low angle planar laminae together with characteristic trace fossil assemblages, allow the palaeobathymetric interpretations to be made. Qualitative palaeobathymetric curves have been constructed for the 10 sequences (Fig. 4 and 10A-C) from our integrated proxy depth dataset. The uncertainty of the curves ranges from $\pm 50 \mathrm{~m}$ on the mid-outer shelf to $\pm 5 \mathrm{~m}$ on the foreshore. 


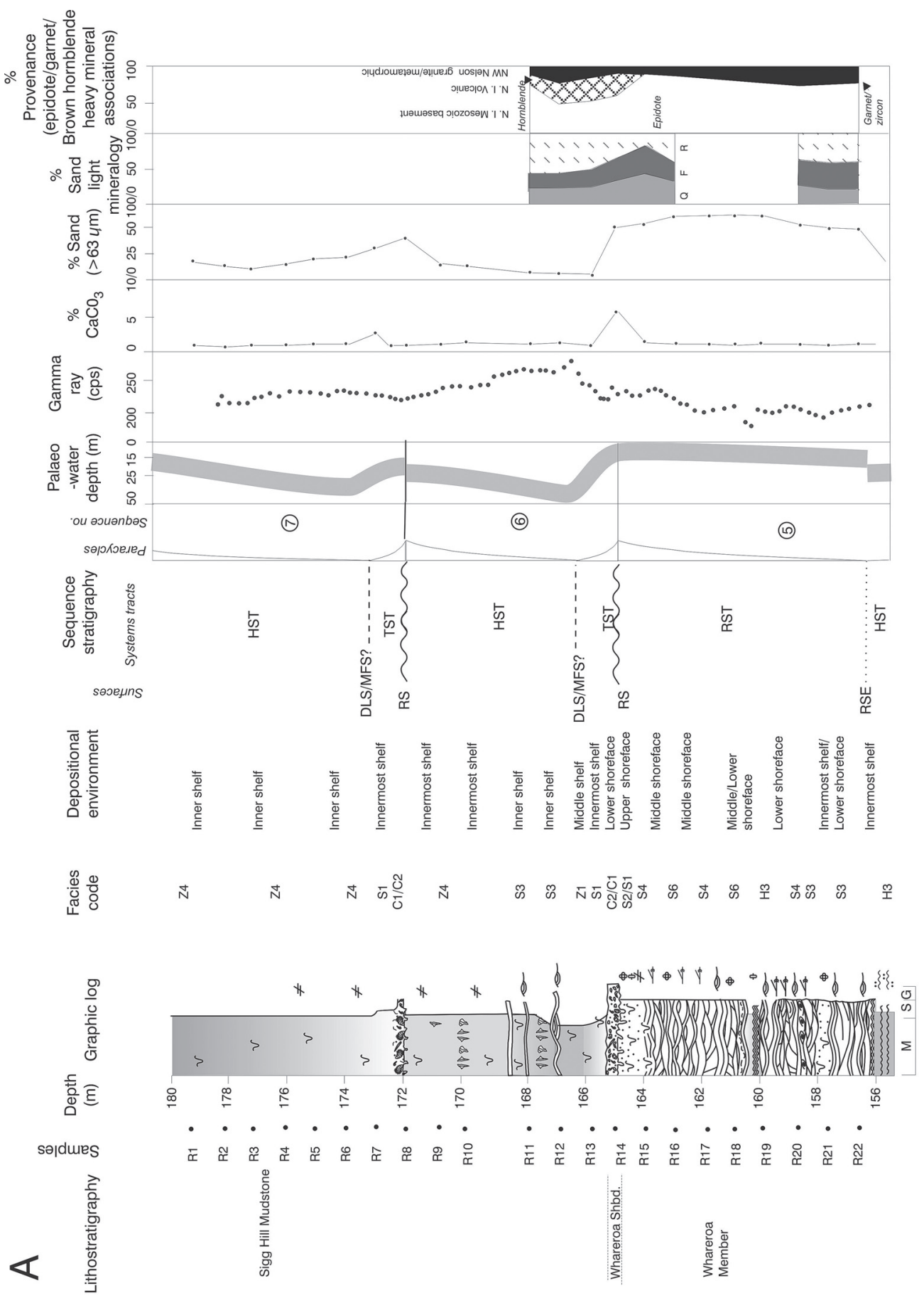

Fig. 10 High resolution variations in multi-proxy environmental datasets for selected intervals of the Tangahoe Formation showing lithofacies, depositional environment, sequence stratigraphy, palaeobathymetry, natural gamma (counts per second), percentage calcium carbonate, percentage sand, and light and heavy mineralogical data. A, Rifle Range section at base of dairy factory outfall access track. 


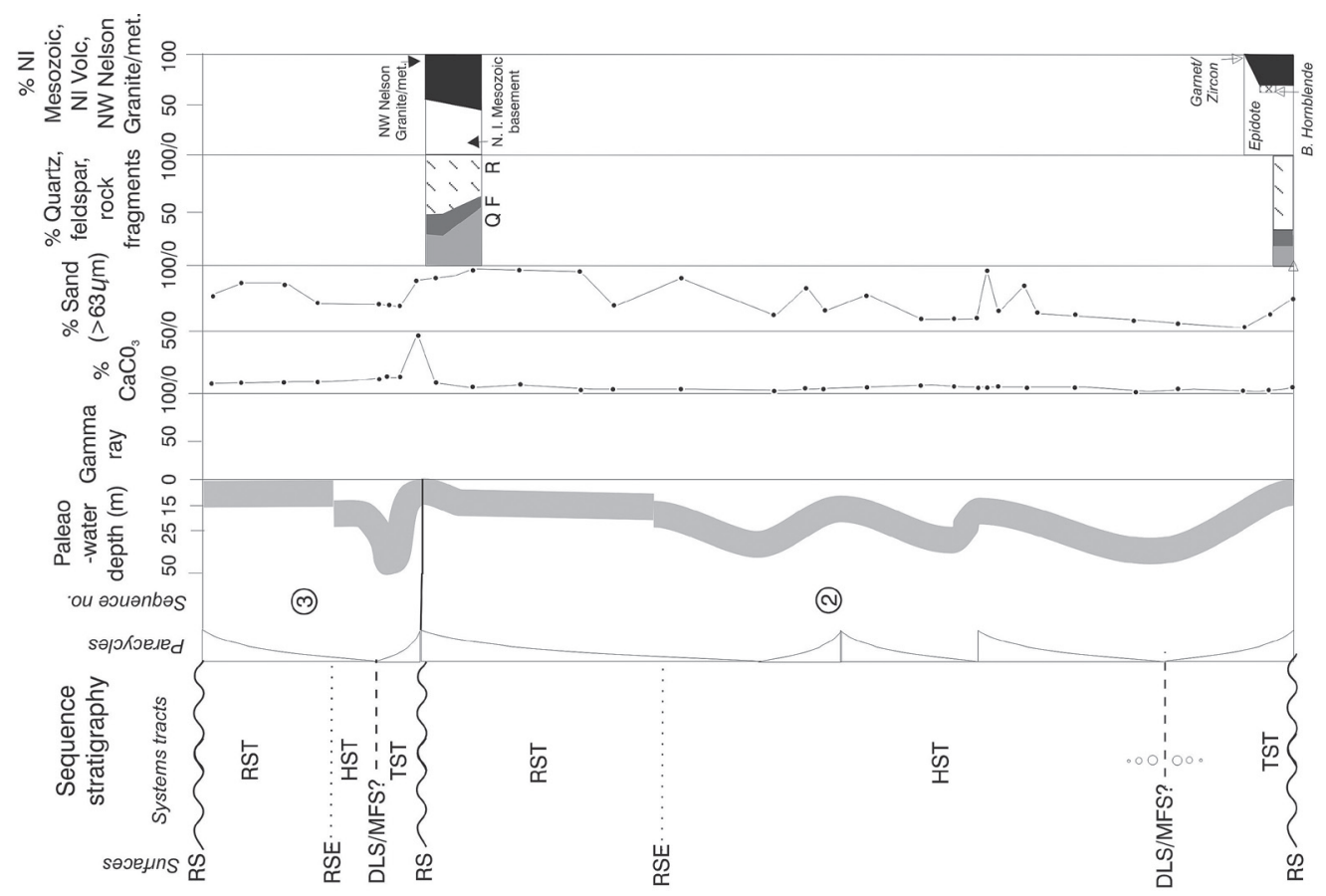

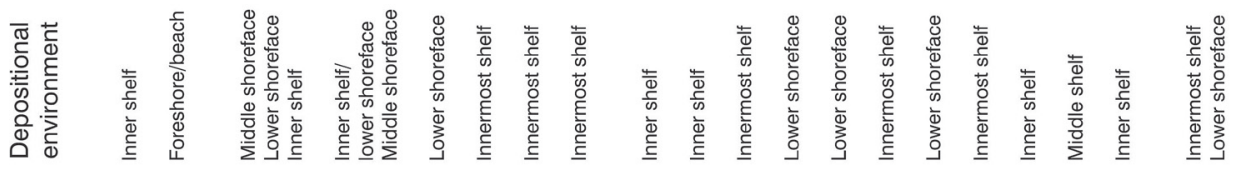

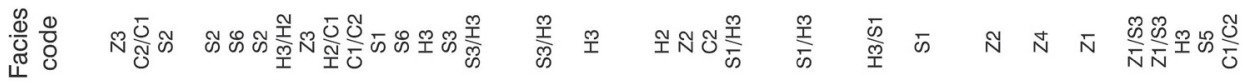

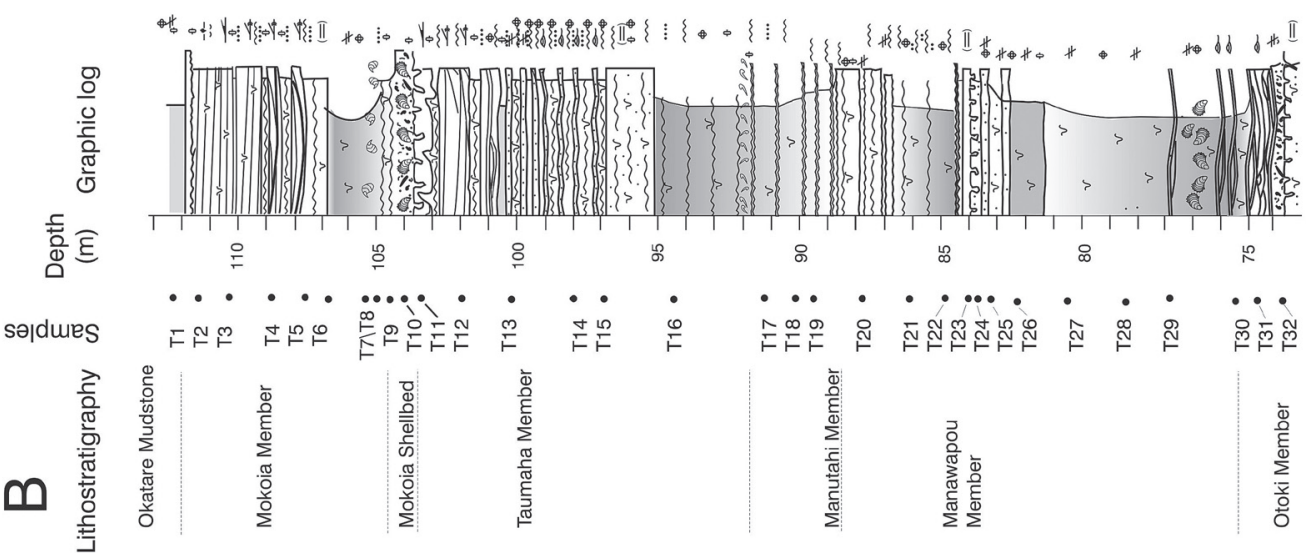

Fig. 10 (continued) B, Tangahoe Beach section. 


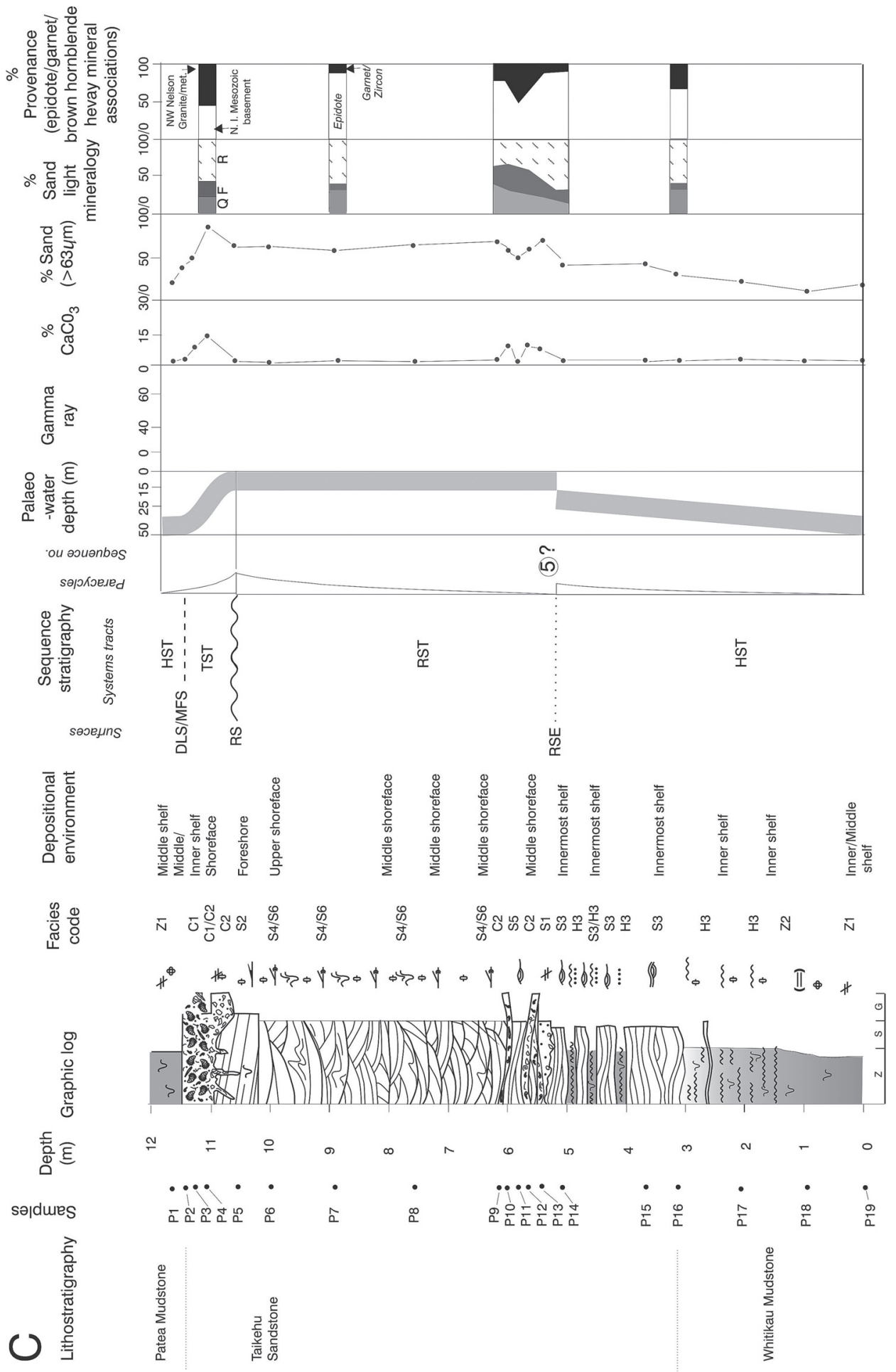

Fig. 10 (continued) C, Patea Beach section. Also see Fig. 2 for locations of sections. 
Faunally derived depth changes within sequences support the lithofacies and sequence stratigraphic inferences regarding water depth. TSTs show a clear deepening from shoreline to offshore shelf depths. The level of resolution provided by the palaeobathymetric data is insufficient to resolve the precise position of the maximum water depth. However, typically the maximum water depth in each sequence corresponds to a 5-10 $\mathrm{m}$ zone, spanning the top of the TST and the lower part of the HST. A progressive shoaling trend to shoreline and marginal-marine environments is indicated through the HST-RST transition.

The amplitude of water depth change implied for individual sequences ranges from 10 to c. $50 \mathrm{~m}$. While we recognise a significant subsidence contribution to the generation of accommodation and palaeobathymetric change (e.g., Kamp \& Naish 1998; Naish 1998) during these relative sea-level changes, the amplitude of water depth change is consistent with fluctuations in glacio-eustatic sea level estimated from deep sea oxygen isotope records for the mid-Pliocene (see below).

\section{HIGH RESOLUTION MULTIPROXY ANALYSIS OF TANGAHOE FORMATION SEQUENCES}

Three particularly well exposed and accessible sections were selected for a higher resolution analysis of the depositional cyclicity within the Tangahoe Formation.

(1) Rifle Range Road section (Fig. 10A) spans the HST-RST transition of Sequence 5, Sequence 6, and the lower part of Sequence 7, and includes the Whareroa Member, Whareroa Shellbed, and the Sigg Hill Mudstone.

(2) Tangahoe Beach section (Fig. 10B) spans two complete sequences (Sequences 2 and 3) and includes the Otoki Member, Manawapou Member, Manutahi Member, Mokoia Shellbed, Mokoia Member, and Okatare Mudstone.

(3) Patea Beach section (Fig. 10C), is located stratigraphically on the south-eastern limb of the anticline and is tentatively correlated with Sequence 2 in the Tangahoe Beach section. Though its exact stratigraphic position has not been established, it provides an excellent example of an HST-RST transition.

Figure $10 \mathrm{~A}-\mathrm{C}$ shows systematic variations in natural gamma-ray, percentage $\mathrm{CaCO}_{3}$, percentage sand, and light and heavy mineral composition of the selected sequences. These variations represent environmental proxies that provide additional support to the sequence, facies, and palaeobathymetric interpretations, as well as some additional new information on sediment provenance and environmental influences on provenance.

\section{Grain size: palaeobathymetric indicator}

Grain size analyses were undertaken on samples to investigate sedimentary cyclicity at the sequence and intrasequence scale, and as a qualitative estimate of palaeobathymetry. The stratigraphic variations in grain size and lithofacies illustrated in Fig. 10A-C primarily reflect variations in depositional energy on a wave graded, open coastline and shelf, and thus should track changes in bathymetry through a sequence. Analyses were carried out at the Institute of Geological and Nuclear Sciences Sedimentology Laboratory, using a Coulter LS-130 laserdiffraction particle size analyser fitted with a $300 \mathrm{~mm}$ focal length lens.

Analyses were made in the range of $900-0.06 \mu \mathrm{m}$. Samples were prepared by gentle handcrushing (between finger and thumb) while in field moist condition. Bivalve shell fragments were clearly visible, so were picked out by hand. In order to remove organic matter and further aid disaggregation, samples were subsequently immersed in $10 \% \mathrm{H}_{2} \mathrm{O}_{2}$ solution and placed in a heated $\left(85^{\circ} \mathrm{C}\right)$ ultrasonic water bath for c. $1 \mathrm{~h}$, or until inspection under binocular microscope showed complete disaggregation to primary depositional grain sizes. Following this, samples were then centrifuged at $3000 \mathrm{rpm}$ for $15 \mathrm{~min}$ and the supernatant liquid decanted. 
Any remaining carbonate was treated with $10 \% \mathrm{HCl}$ until effervescence ceased. All samples were then re-washed in water and centrifuged. Once the supernatant liquid had been removed, the solids were resuspended in $50 \mathrm{ml}$ of water and sonicated for a further $10 \mathrm{~min}$ and wet sieved at $1000 \mu \mathrm{m}$ to remove coarse sediment immediately before analysis.

Variations in sand content upsection within Tangahoe sequences (Fig. 10A-C) show close correspondence to vertical changes in lithofacies with time. The lower parts of sequences display a rapid fining upwards trend from sandy and pebbly shellbeds (facies $\mathrm{C} 1$ and $\mathrm{C} 2$ ) and hummocky cross-stratified fine sandstone (facies S3) of the transgressive systems tract to sandy mudstone (Z4) and mudstone (Z2 and Z1) of the HST. Sand content progressively decreases upwards from $100-60$ to $<10 \%$. The transition to fine grained facies across the downlap surface is abruptly gradational, in most cases occurring over a 1-5 $\mathrm{m}$ interval. The base of the HST is characterised by sparsely fossiliferous, bioturbated mudstone (Z2 and Z1) (<10-30\% sand). Upper parts of sequences display an overall coarsening upwards regressive lithofacies succession from mudstone to sandy mudstone (Z4 and Z5) to hummocky and swaly cross-stratified fine sandstone (S3 and S5) in the top of the HST, to well sorted trough cross-stratified and low angle planar cross-stratified sandstone (facies S2 and S4) with increasing amounts of coarser grained sand and gravel, and tractional sedimentary structures in the overlying regressive systems tract. Sand content increases upward from $<30 \%$ up to $100 \%$. Where the coarsening upward regressive succession at the top of the HST is truncated by a wave cut erosion surface at the base of the shoreface facies succession (regressive surface of erosion (RSE) - see later discussion), the transition from fine grained to coarse grained sediments may be abrupt and in some cases marked by minor erosional relief.

\section{Gamma ray: recognition of the mid-cycle condensed section}

The gamma ray logging was only undertaken for the Rifle Range Road section. Total natural gamma radiation (U-Th-K) was measured with a hand held Scintrex scintillometer GRS-500 at $10 \mathrm{~cm}$ intervals through the section. Each site was measured five times and an average value plotted against depth in Fig. 10A. Gamma logs record the radioactivity of the sediments. Fine grained, clay rich mudstones have a higher radioactive uranium and potassium content than quartz and plagioclase rich sandstones. The gamma log displays a positive shift from quartz-feldspar-mica sands of the RST of Sequence 5 into progressively muddier, K rich, illite dominated sediments of the TST of overlying Sequence 6. The "hottest" interval on the gamma log corresponds to the inferred position of the deepest part of Sequence 6 and the TST/HST boundary. In sequence stratigraphic terms this position has been referred to as the "condensed section" (Baum \& Vail 1988), or the maximum flooding surface (MFS; e.g., Vail 1987). In low resolution seismic studies the MFS is broadly coincident with the downlap surface (DLS), which marks the "turnaround" from onlapping to offlapping depositional systems (van Wagoner et al. 1988). However, higher resolution studies (Carter et al. 1998) have shown that for shallow-marine, Milankovitch-scale sequences the MFS is a theoretical horizon that may not necessarily correspond to the deepest point in a sequence. The stratigraphic interval $(10 \mathrm{~cm})$ of our "hottest" gamma value overlies a thin condensed shellbed, broadly corresponds to the deepest part of the sequence, contains $95 \%$ mud $(<63 \mu \mathrm{m})$, and is inferred to represent the lowest sedimentation rates in the sequence. Such intervals of high gamma radiation are considered to reflect a combination of stratigraphic condensation and increased potassium rich clay content, and are referred to in the oil industry as "hot shales".

\section{Percentage calcium carbonate: sedimentation rate proxy}

The variation in percentage $\mathrm{CaCO}_{3}$ through a sequence, together with the shellbed characteristics, highlights variation in the supply of terrigenous sediment to the depositional environment. 
The $\mathrm{CaCO}_{3}$ component within sequences is entirely composed of bioclastic material, predominantly derived from contemporaneous communities of molluscs with subordinate contributions from other marine invertebrates, such as brachiopods, barnacles, bryozoans, echinoderms, and benthic foraminifera. The abundance of these organisms is directly related to the sedimentation rate. Consequently, within condensed fossiliferous deposits associated with TSTs and shell lags, the sedimentation rates are low (c. $0.1 \mathrm{~m} / \mathrm{ka}$ ), and $\mathrm{CaCO}_{3}$ concentrations range from 5 to $50 \%$. Highstand siltstones and regressive sandstones display sedimentation rates between 0.5 and $1.5 \mathrm{~m} / \mathrm{ka}$ and low $\mathrm{CaCO}_{3}$ concentrations, generally $<1-2 \%$.

\section{Sand petrography: provenance controls on sequence development}

\section{Light fraction mineralogy}

Representative samples from the sequences in Fig. 10A-C were thin sectioned and treated with barium chloride, potassium rhodizonate, and cobalt nitrate for petrographic analysis of their mineralogy. Staining helped elucidate plagioclase and K-feldspars. Point counts were made of 300 grains for each sample. The sampling was not comprehensive and was stratigraphically incomplete. However, sufficient representative samples from the various facies and systems tracts enabled some broad inferences to made regarding provenance of the sediments. The petrographic data are summarised and interpreted on ternary discrimination plots in Fig. 11A,B (data available at http://data.gns.cri.nz/).

Samples are mainly litharenites and feldspar litharenites, dominated by sedimentary lithics (50-80\%), quartz (10-50\%), plagioclase and K-feldpsar (0-40\%) (Fig. 11A). Subordinate mica $(<1 \%)$ occurs in mudstones and up to $10 \%$ in sandstones. Figure $11 \mathrm{~A}$ shows how the relative proportions of quartz, feldspar, and lithics vary depending on their stratigraphic position within a sequence. Well sorted, sandy shallow water facies within RSTs comprise higher proportions of quartz and feldspar than deeper water facies of the HSTs and TSTs, which are dominated by lithic fragments. That lithic fragments are mainly siltstone, and do not appear to be heavily indurated, is consistent with recycling of uplifted Neogene sedimentary strata along western North Island.

\section{Heavy fraction mineralogy}

Heavy minerals were separated from the $2-4 \phi$ fraction of the grain size distribution of each sample using standard heavy liquid specific gravity separation methods. Proportions were established by point counting 300-500 individual grains per sample. Tabulated proportions of heavy mineral content are also available at http://data.gns.cri/nz/.

Heavy minerals are dominated by the epidote group (5-15\%), non-magnetic opaques (25-45\%), semi-opaque debris (11-44\%), and green hornblende (3-11\%), and are typical of low grade metamorphic Mesozoic basement provenance (e.g., Murihiku or Torlesse). However, two other subordinate, but distinct, populations were identified in samples; a volcanic component, dominated by green clinopyroxene, brown hornblende, and magnetic opaques of andesitic origin, and a garnet-zircon dominated assemblage with associated sillimanite, chloritoid, and andalusite, distinctive of a high grade metamorphic source. The association of sillimanite, chloritoid, and andalusite is characteristic of north-west Nelson (e.g., Pikikiruna Range; Ghent 1968; Railton \& Watters 1990). Hutton (1940), in the first description of the mineralogy of the Tangahoe Formation, noted that the heavy minerals were derived from granitic and metamorphic rocks.

The relative proportions of the three heavy mineral assemblages are plotted on a ternary diagram in Fig. 11B to illustrate partitioning of the heavy mineral composition within sequences. The andesitic volcanic assemblage is restricted to samples from TSTs, while the 


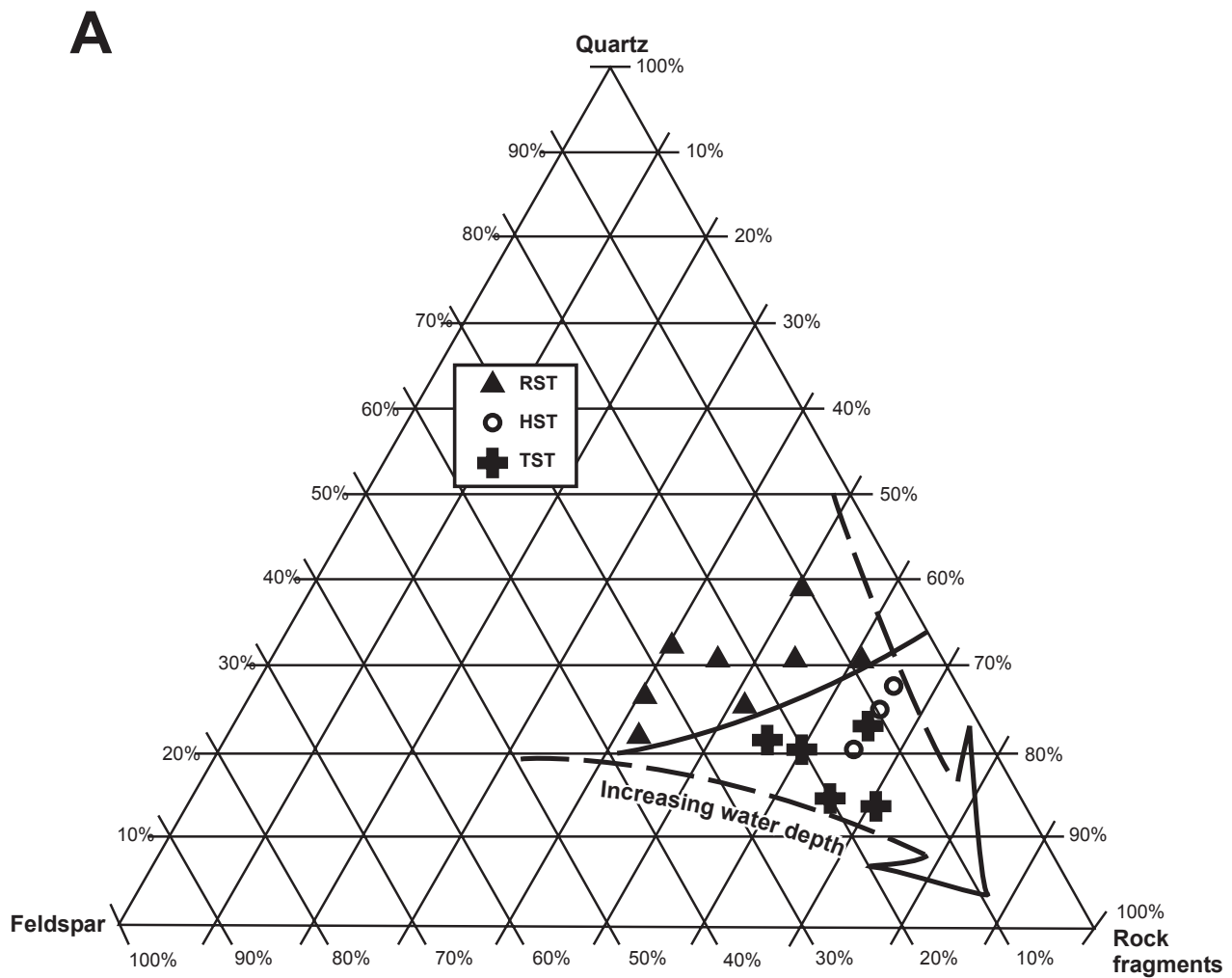

Fig. 11 Ternary plots of petrographic data. A, QFL plot of samples coded with respect to position in sequence (systems tract).

heavy mineral component of HST and RST samples are a mixture of low grade metamorphic Mesozoic basement and high grade metamorphic north-west Nelson signatures.

\section{CHRONOSTRATIGRAPHIC ANALYSIS}

\section{Biostratigraphy}

The presence of rare Globorotalia inflata places the age of the Tangahoe Formation no older than latest Opoitian Stage (Morgans et al. 1996). First occurrence G. inflata occurs in C3n.1, 3.6 Ma in Opoitian lectostratotype (e.g., Edwards 1987). Notorotalia kingmai which also occurs in samples, becomes extinct in the Mangapanian (3.0 Ma). This, together with the common occurrence of the Waipipian Stage index molluscan taxa Mesopeplum crawfordi and Philopecten marwicki, restricts the age of the Tangahoe Formation sequences described in this paper to the Waipipian Stage (3.6-3.06 Ma; Carter \& Naish 1998).

\section{Palaeomagnetism}

For the coastal section of the Tangahoe Formation, 160 standard oriented (25 mm diameter) palaeomagnetic cores were collected from 532 sites (Wehland 1999). Cores were shielded from collection until measurement on a CCL cryogenic magnetometer housed in the palaeomagnetic laboratory at the University of Oxford, United Kingdom. All samples were subject to stepwise thermal demagnetisation using a Magnetic Measurements Thermal Demagnetiser (MMTD). 


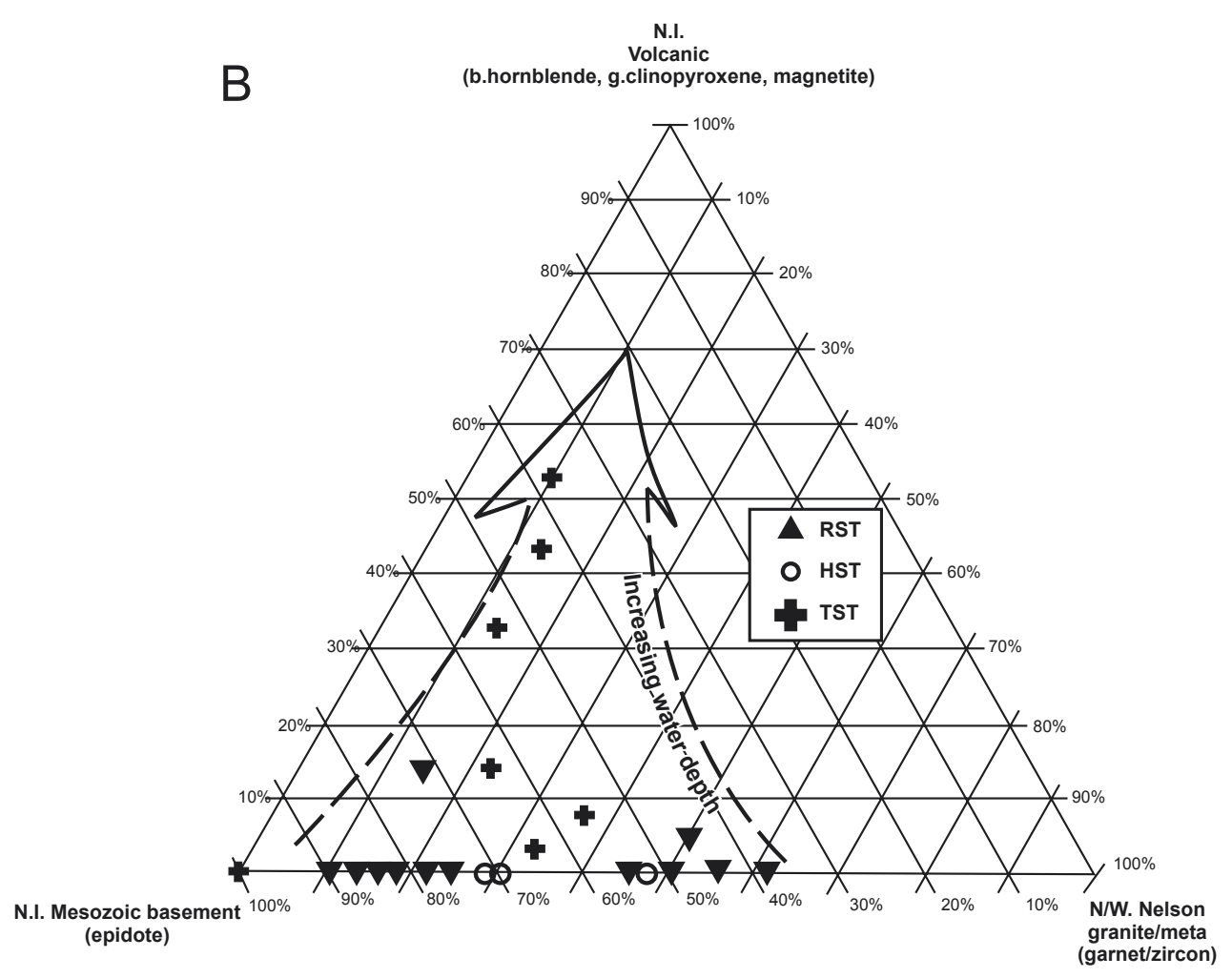

Fig. 11 (continued) B, Plot of the three provenance areas interpreted from the heavy mineral assemblages. Samples are coded with respect to sample position in sequence (systems tract).

Samples were heated and remeasured at $50^{\circ} \mathrm{C}$ increments until magnetic susceptibility measurements indicated new mineral growth induced by heating and prevented further measurement (usually between $300^{\circ} \mathrm{C}$ and $400^{\circ} \mathrm{C}$ ). Thermal demagnetisation was used in preference to alternating field demagnetisation because previous palaeomagnetic studies of Wanganui Basin sediments have indicated that thermal demagnetisation was more effective in isolating primary remanences and stable endpoints (e.g., Pillans et al. 1994; Wilson \& Roberts 1994).

Two main interpretative methods were used to identify characteristic site remanence directions. Where possible, linear trends were isolated for discrete samples from orthogonal vector component plots using a free line fit (Butler 1992). But, where it was not possible to identify characteristic remanence directions because of significant overlap in blocking temperature spectra of characteristic and secondary components of magnetisation, or because of thermal alteration during demagnetisation, site directions were identified using remagnetisation great circle analysis on stereographic projections of demagnetisation data.

Sample NRM intensities range between $10^{-5}$ and $10^{-5} \mathrm{~A} / \mathrm{m}$, and the behaviour of most samples was sufficiently stable to identify characteristic remanence directions from orthogonal components plots of demagentisation data (Fig. 12). Three classes of sample behaviour were identified from demagnetisation data: Class A samples display single demagnetisation components directed towards a common endpoint that was displaced slightly from the origin of vector component plots (Fig. 12A) with occasional minor viscous or secondary overprints generally removed by heating to $120^{\circ} \mathrm{C}$. Class B samples are similar to class A samples in 
their behaviour. However, they are generally weaker in their intensity and display more noisy behaviour on vector component plots. Primary polarity was confidently identified (Fig. 12B,C). Class $\mathrm{C}$ samples are very weak and stable endpoint directions cannot be confidently identified. Only class A and B samples were used to identify primary polarity for the mid-Pliocene coastal Tangahoe Formation sequences (Fig. 13). Where samples displayed class C behaviour, primary polarity was not determined.

Unblocking temperature spectra and Isothermal Remanent Magnetisation experiments (Wehland 1999) compare favourably with previous rock magnetic studies of Pliocene strata from Wanganui Basin (Wilson \& Roberts 1994) and indicate that the primary remanence carrier is either titanomagnetite or ilmenite with a common goethite authigenic phase. Samples with coarser textures (sandy siltstones) commonly showed stable characteristic remanence directions that did not lean towards the origin of orthogonal vector component plots. This is potentially due to the additional presence of authigenic hematite resulting in a high temperature secondary component of magnetisation that was not isolated before thermal alteration of samples prevented further demagnetisation (cf. Wilson \& Roberts 1994).

The quality of the data enabled an N-R-N-R-N (upward) polarity zonation to be interpreted for the 10 Tangahoe Formation sequences (Fig. 13). Polarity transitions occur at 24, 177, 198 , and $243 \mathrm{~m}$ above the base of the coastal section. Given that the entire coastal section is biostratigraphically confined to the Waipipian Stage, we have correlated the N-R-N-R-N magnetic polarity sequence to chrons C2An.3n-C2An.2r (Mammoth)-C2An.2n-C2An.1r (Kaena)-C2An.1n, respectively, of the geomagnetic polarity timescale (GPTS) of Cande \& Kent (1995).

\section{Age model and cyclostratigraphy}

The magnetostratigraphic data outlined here, supported by the biostratigraphic information, allow individual mid-Pliocene Tangahoe Formation sequences to be correlated directly to the oxygen isotope $\left(\delta^{18} \mathrm{O}\right)$ timescale. A number of high resolution $\delta^{18} \mathrm{O}$ records are now available for the Pliocene from both the Atlantic Ocean (ODP Site 659, Tiedemann et al. 1994) and the Pacific Ocean (ODP Site 846, Shackleton et al. 1995), which provide global reference records of Pliocene ice volume/sea-level changes. An advantage of making these correlations is that they permit age estimates to be made for stratigraphic horizons and events not used in establishing the correlations (e.g., sequence boundaries), the duration/frequency of sedimentary cyclicity to be established, and inferences regarding time represented at sequence bounding unconformities to be drawn. We present an age model for the Tangahoe Formation sequences in Fig. 13 that is constructed from correlating the ODP Site $846 \delta^{18} \mathrm{O}$ timescale to the magnetic polarity zonation of the Tangahoe Formation. Our age model implies that the section (Sequences 1-10) spans 3.36-3.06 Ma, an interval of $300000 \mathrm{yr}$, and that the average duration for each unconformity-bound sedimentary sequence is $30000 \mathrm{yr}$.

Palaeobathymetric changes within the Tangahoe Formation outcrop, described above and illustrated in Fig. 4 and 13, show seven major cycles of shallowing and deepening from shelf to shoreline environments during the deposition of Sequences 1-10. These cycles in bathymetry are labelled A-G in Fig. 13 and do not always correspond to individual sequences. In two cases, these major bathymetric cycles span two or more sedimentary sequences. Thus, Sequences 3,4 , and 5 are interpreted as the products of three higher frequency, smaller scale cycles of sea level superimposed on the longer duration bathymetric Cycle C. Likewise, Sequence 10 is regarded as a minor deepening and shallowing cycle during bathymetric Cycle G, which spans both Sequences 9 and 10. Our rationale has been to identify the major changes in palaeobathymetry occurring in the coastal section, independently of the sequence stratigraphy, by the integration of palaeoecologic and facies datasets. While the sequence architecture is 
A
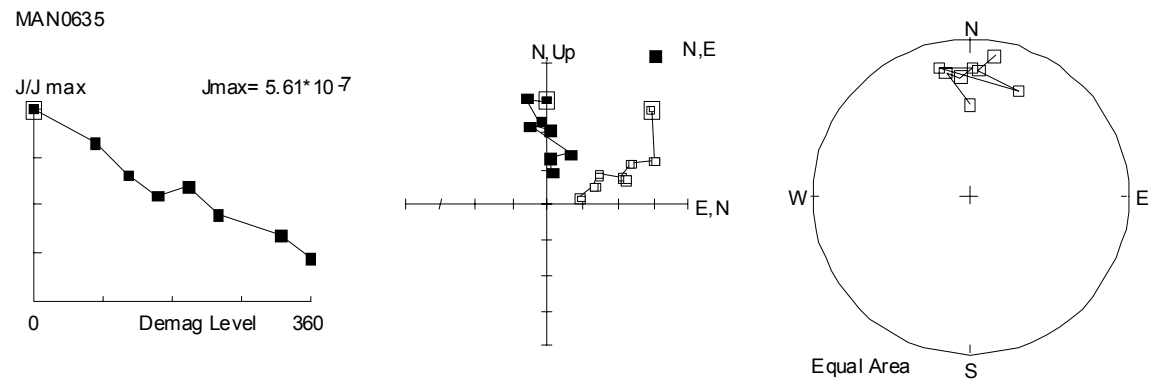

$\mathrm{B}$

TR1889
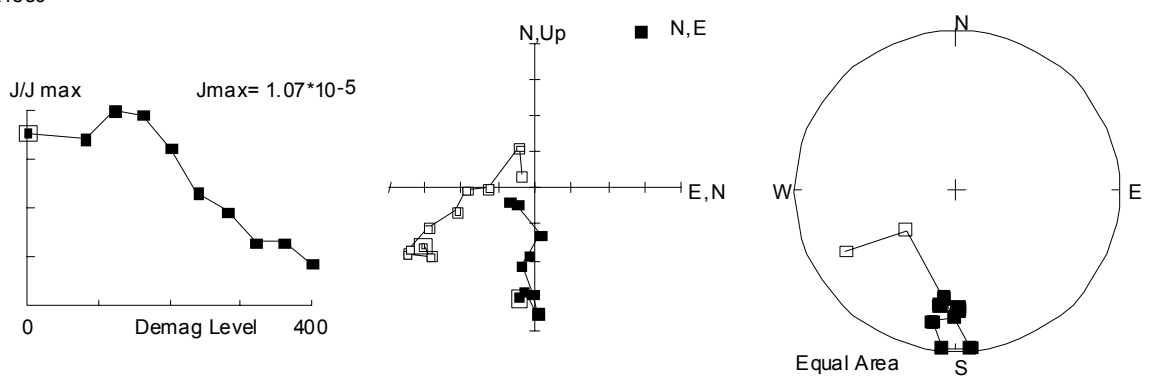

C
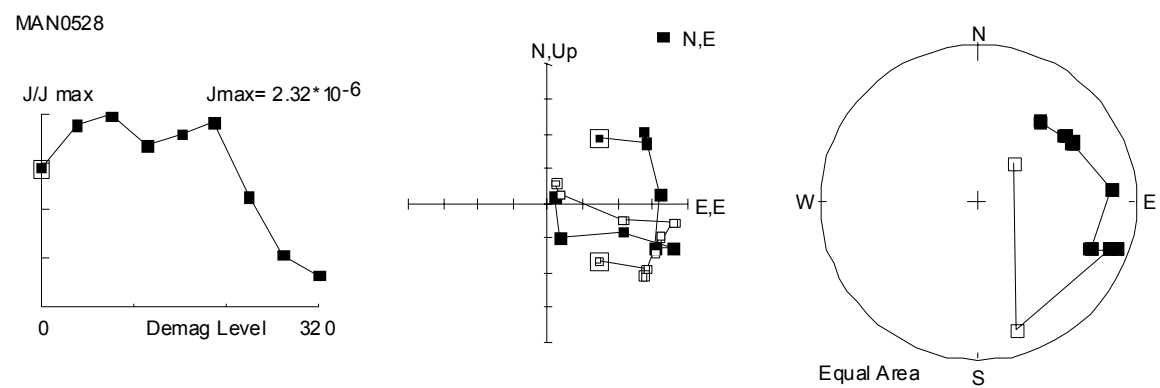

$\mathrm{D}$
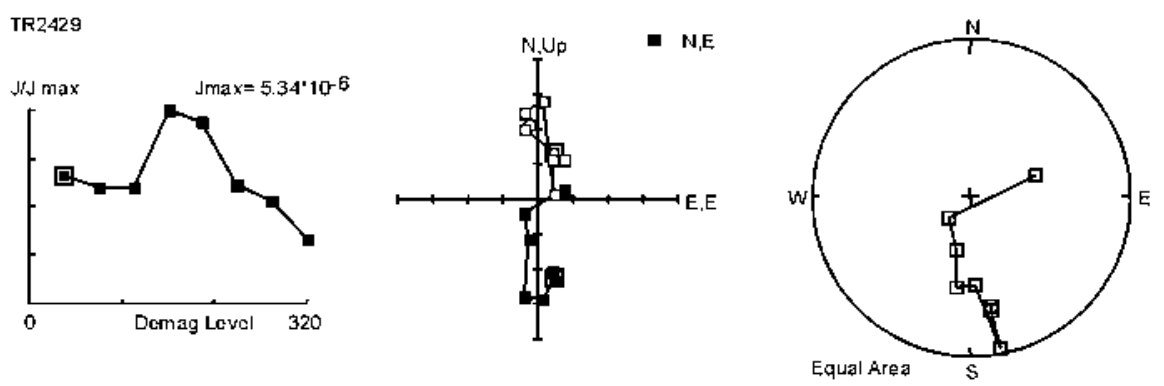

Fig. 12 Vector component plots showing representative palaeomagnetic behaviour on thermal demagnetisation for samples from the Tangahoe Formation coastal section. A,B, A Class behaviour. C, B Class behaviour. D, D Class behaviour. 


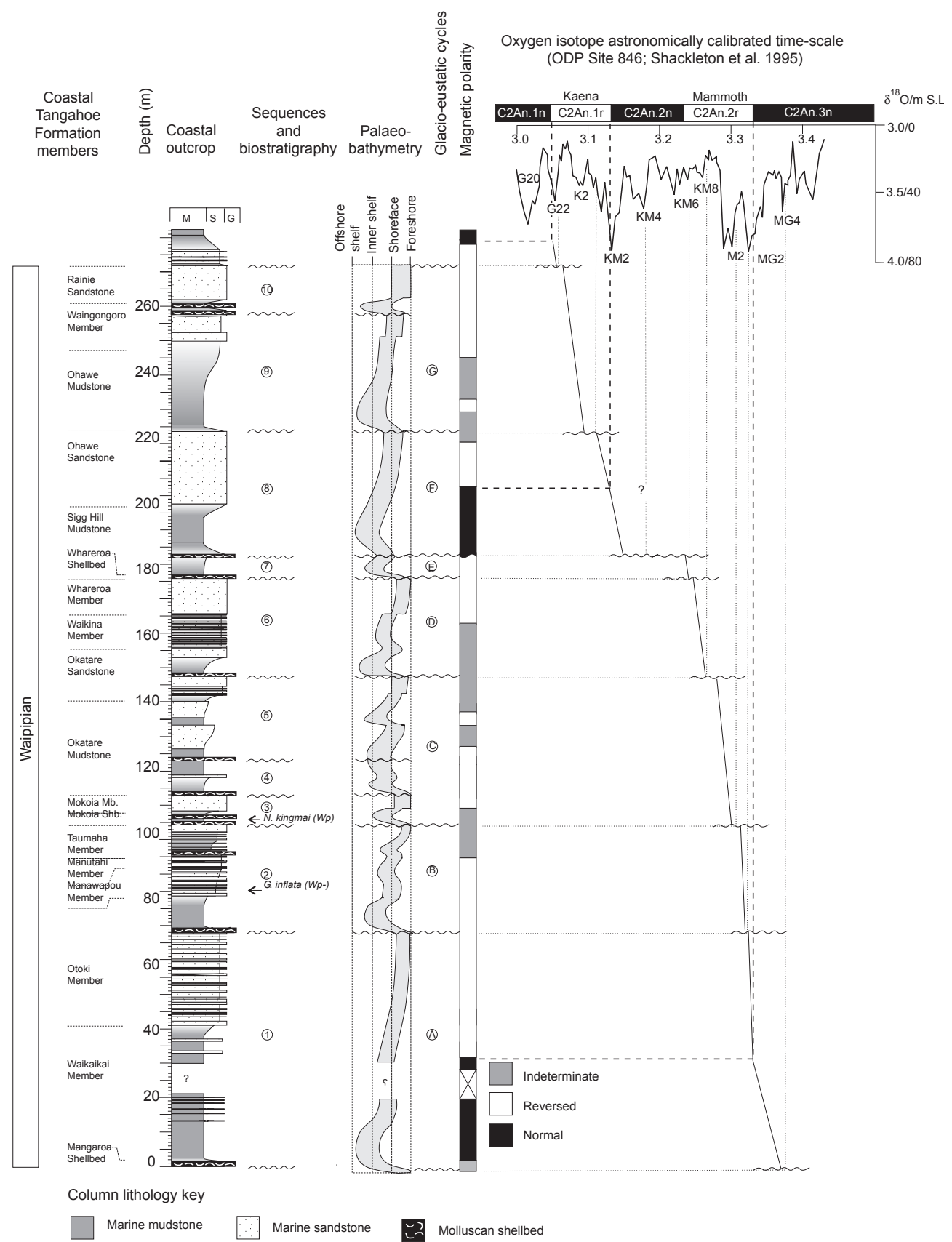

Fig. 13 Magnetic polarity zonation for the Tangahoe Formation coastal section and correlation to the oxygen isotope timescale of Shackleton et al. (1995). The timescale is based on an astronomical calibration and is the same calibration used in the Pliocene part of the geomagnetic polarity timescale (Cande \& Kent 1995). A sea-level conversion is shown for $\delta^{18} \mathrm{O}$ variation, which is based on the Quaternary coral terrace calibration of Chappell \& Shackleton (1986) and the ODP Site 846, which is largely an ice volume record (Tiedemann et al. 1994; Naish 1998). A correlation of glacio-eustatic cycles (based on the faunally derived palaeobathymetry curve) with the $\delta^{18} \mathrm{O}$ record is shown, and indicates a strong $41000 \mathrm{yr}$ obliquity-controlled climatic influence on water depth changes during deposition of the Tangahoe sequences. 
clearly sensitive to a wide range of sea-level changes, some sequences were the consequence of higher frequency change punctuating longer term changes in bathymetry. Our age model implies a duration of c. $40 \mathrm{ka}$ for each of the major bathymetric cycles, which corresponds to the obliquity frequency that dominates glacial-interglacial variability in the global $\delta^{18} \mathrm{O}$ ice volume/sea-level records. Accordingly, we view these sea-level variations as the product of global glacio-eustasy. The higher frequency sea-level changes and sequences may correspond to $20 \mathrm{ka}$ precessional cycles, or may be autocyclic in origin.

\section{DISCUSSION}

\section{A depositional model for mid-Pliocene sequences of the Tangahoe Formation}

\section{Lowstand deposition}

While not exposed in outcrop, contemporary lowstand sediments that accumulated on the outer shelf and basinward of the glacial maximum lowstand shoreline are well expressed in seismic reflection profiles (Beggs 1990; Hansen \& Kamp 2002). They comprise an obliquely offlapping series of lowstand prograding wedge systems tracts (LST), known as the Giant Foresets Formation, and display steeply dipping clinoforms representing progressive outbuilding of the outer shelf and continental slope during successive Pliocene sea-level cycles.

Landward of the glacial maximum lowstand shoreline, relative sea-level lowstands would have been represented by subaerial exposure of the shelf, channel incision, and terrestrial sedimentation on a broad low angle coastal plain. However, in all Tangahoe Formation sequences, these terrestrial deposits are removed by wave base erosion processes during ensuing shoreline transgressions. The preservation potential of the coastal plain facies beneath the sequence boundary is generally poor in Pliocene-Pleistocene shelf sequences (Abbott \& Carter 1994; Kitamura et al. 1994; Naish \& Kamp 1997a).

\section{Transgressive deposition}

Shallow water, reworked onlap shellbeds that overlie sequence boundaries represent initial marine onlap as the shoreline passes landward during rising relative sea level. On the basis of their constituent fauna and sedimentary structures, we infer that these deposits accumulated in a range of coastal depositional settings. In most cases these shallow water deposits grade rapidly up into in situ matrix supported backlap shellbeds of more offshore shelf affinity, indicative of rapid drowning and terrigenous starvation of the shelf during the majority of the transgression. Transgressive terrigenous sediments are inferred to be restricted to the nearshore regions. The deposition of these transgressive coastal strata was controlled by the rate and magnitude of sea-level rise and the rate of sediment supply. Thus, they probably accumulated rapidly when transgressions were punctuated by stillstands and small progradational events. Coastal transgressive sediments onlap the sequence boundary, infill palaeo-relief in the underlying RST, and generally deepen upwards.

\section{Highstand deposition}

All 10 sequences in the Tangahoe Formation display a sparsely fossiliferous, bioturbated shelf siltstone interval overlying fossiliferous transgressive sediments. In its present and Holocene highstand state, the South Taranaki Bight continental shelf displays thin, patchy and isolated deposits of river borne, fine grained sediments overlying post-last glacial transgressive coastal deposits and relict/palimpsest carbonate sediments (Gillespie \& Nelson 1997). Unlike the modern continental shelf, HST sediments in the Tangahoe Formation and other PliocenePleistocene Wanganui Basin sequences display thick (up to $30 \mathrm{~m}$ ) aggradational intervals of bioturbated mudstone and fine sandy mudstone (e.g., Naish \& Kamp 1997a). The basal 
contacts are abruptly gradational and imply a dramatic switching on of terrigenous sediment supply. Moreover, a grid of industry seismic reflection profiles from Taranaki Peninsula to Farewell Rise interpreted by Ogilvy (1993) display strong north-eastward prograding clinoform geometries during inferred regressions in the Waipipian. Abbott (2000) noted that the lack of a mud blanket on the modern shelf during the present highstand may suggest that significant accumulation of terrigenous sediments on the shelf does not commence until sea level begins to fall (i.e., early forced regression). Upper portions of HST mudstones progressively increase in sand content and display wavy beds and laminae of sand, and hummocky cross-stratified sand introduced to the inner shelf during frequent episodic storm events. As the rate of sealevel fall increases, accommodation on the shelf is reduced as wave base lowers, leading to erosion on the innermost shelf and formation of the regressive surface of erosion (Nummedal \& Molenaar 1995), or an abrupt transition into lower shoreface sandstone of the RST.

\section{Forced regressive deposition}

As the rate of sea-level fall increases under conditions of "forced regression" (Posamentier et al. 1992), the shoreface progrades rapidly or is abruptly translated basinward onto the area of the former shelf (Fig. 14). In the latter case the shoreface/foreshore facies assemblage may overlie a zone of wave base erosion, or sediment bypassing represented as a thin shell lag on a sharp erosion surface. In a number of the Tangahoe Formation sequences, HST siltstones are abruptly overlain by sharp based shoreface sandstones interpreted as the products of a forced regression on the inner shelf. In these cases, storm influenced, fine, sandy inner shelf siltstones displaying hummocky cross-stratification are sharply overlain by well sorted, trough crossstratified, lower shoreface sandstone interpreted to represent rip channels in the shoreface. However, where the transition from HST mudstone to shelf siltstone is not erosional, an interval of innermost shelf swaley cross-stratified sandstone is preserved. This classical sedimentary architecture of sharp based and gradationally based shoreface deposits was first recognised by Plint (1988) in the Cardium Formation of the Cretaceous Western Interior Seaway of Canada. Since Plint's work, the sequence stratigraphic significance of these deposits has been discussed by numerous authors (e.g., Hunt \& Tucker 1992; Posamentier 1992; Nummedal \& Molenaar 1995; Naish \& Kamp 1997a). While semantic arguments persist as to the correct terminology of such deposits, it is now widely accepted that they represent the product of forced regression on a storm dominated open coastline.

Shoreline sediments can accumulate on the shelf during lowering base level (reducing accommodation) if newly exposed shelf gradients are less steep than the permanently subaerial coastal plain (Miall 1991; Posamentier et al. 1992; Schumm 1993; Wood et al. 1993; Woolfe et al. 1998; Browne \& Naish 2003). As forced regression ensues, the shoreline is transposed several tens of kilometres to the west across the former continental shelf and a broad coastal plain (sequence boundary) develops.

\section{Sequence stratigraphic significance of sand provenance}

Transgressive systems tracts are dominated by sedimentary lithic fragments with a minor andesitic volcanic lithic component, and display a heavy mineral assemblage characteristic of derivation from central North Island andesite volcanoes. The age of the Tangahoe Formation precludes Taranaki Volcano as a source, but is consistent with the age of older Taupo Volcanic Zone andesite sources such as Hauhungaroa Volcano (Stipp 1968), and the Alexandra Volcanics in the Waikato region (Briggs et al. 1989). Moreover, andesitic volcanics south of Kawhia Harbour, Orangiwhao and Whareorino, also appear to be of Pliocene age (Fleming 1953). The predominance of North Island derived volcanic sediments along with recycled sedimentary lithics probably occurred during transgressive marine erosion as the shoreline 


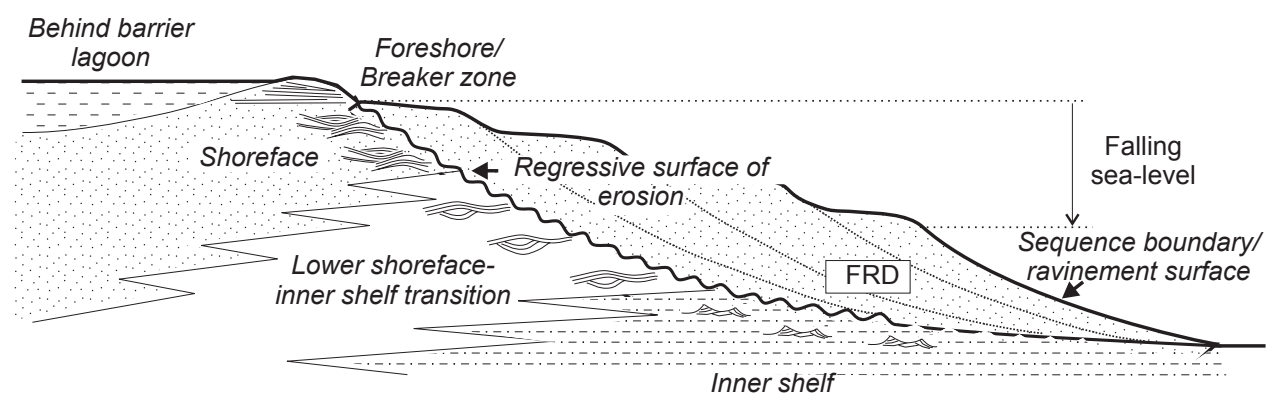

Fig. 14 Generic model of the depositional architecture of the shoreface and inner shelf during forced regression (modified from Plint 1988). This architecture is observed in sharp-based regressive systems tracts of Tangahoe Formation sequences.

moved landward across the subaerially exposed South Taranaki Bight during sea-level transgressions, concentrating locally derived North Island material.

Highstand systems tracts also contain a significant component of recycled siltstone lithics of probable North Island origin together with a heavy mineral assemblage dominated by a north-west Nelson metamorphic and Murihiku/Torlesse greywacke signature, implying an increased South Island provenance for fine grained sediments deposited during sea-level highstands and early sea-level fall.

Regressive systems tracts have a significantly lower lithic component and can be clearly distinguished on the QFR diagram in Fig. 11A from the HST and TST sediments. Moreover, they typically comprise up to $10 \%$ mica with a strong north-west Nelson signature in the heavy mineral fraction.

Our evaluation of the variations in heavy and light mineral composition of samples within a sequence imply an increased influence of South Island-sourced sediment during falling relative sea level and the regressive phase of the sequence, whereas transgressive deposits appear to be dominated more by locally derived North Island sediments. This partitioning of sediment source between high and lowstands of relative sea level within the Tangahoe Formation sequences reflects changes in the palaeogeography of South Taranaki Bight during a sea-level cycle. During falling sea level the shoreline prograded north-westward across the shallow continental shelf forming an extensive coastal plain from present day Farewell Spit towards Cape Egmont, across which rivers delivered sediments from northern South Island directly to contemporary shallow-marine environments to form the late highstand and regressive systems tracts. Conversely, during transgressive phases and sea-level highstands, the region is flooded and the coastline becomes highly embayed, essentially cutting off a direct littoral pathway for South Island-derived sediments. Facies within the transgressive system tract reflect reworking and lagging of locally derived North Island sediments.

\section{Controls on deposition of the Tangahoe Formation and implications for mid-Pliocene glacio-eustatic sea-level changes}

Our knowledge of mid-Pliocene global ice volume change and hence eustatic sea-level change is derived largely from deep ocean $\delta^{18} \mathrm{O}$ records. Correlation of the Tangahoe Formation sequences with the global $\delta^{18} \mathrm{O}$ curve, presented above and in Fig. 13, implies that observed changes in palaeobathymetry occurred every c. $40000 \mathrm{yr}$, and were controlled by Milankovitch-scale glacio-eustasy. Milankovitch theory states that long-term changes in high latitude summer insolation, due particularly to the $40 \mathrm{ka}$ oscillation in Earth's axial tilt, cause 
predictable waxing and waning of continental ice sheets and, therefore, periodic variations in global climate (e.g., Milankovitch 1995).

The cyclicities of all the mid-Pliocene $\delta^{18} \mathrm{O}$ records are highly coherent and in phase at the $40000 \mathrm{yr}$ frequency band (Tiedemann et al. 1994; Maslin et al. 1998), yet the amplitude of $\delta^{18} \mathrm{O}$ change can vary significantly between records from different latitudes and water depths. This is because the record of foraminifera in a particular deep sea core contains both global (ice volume) and regional (temperature, salinity, and the Dole effect, e.g., Shackleton 2000) components. Direct calibration of the ice volume component of deep marine $\delta^{18} \mathrm{O}$ records with actual eustatic sea-level change has been accomplished for the late Pleistocene from studies of coral-terrace sequences (Fairbanks \& Mathews 1978; Chappell \& Shackleton 1986; Pillans et al. 1998). However, whether the same calibration of ice volume, and thus the sea-level component, is valid for the mid-Pliocene $\delta^{18} \mathrm{O}$ records is unclear.

Naish (1998), using a calibration based on eustatic sea-level reconstructions from Late Pliocene shelf cyclothems in the Rangitikei River section, Wanganui Basin, demonstrated that the equatorial Atlantic ODP Site 846 curve was largely an ice volume record assuming a Late Pleistocene $\delta^{18} \mathrm{O}$ calibration of $0.011-0.012 \% \mathrm{~m}^{-1}$ change in sea level. If the same calibration is applied to the mid-Pliocene part of the Site $846 \delta^{18} \mathrm{O}$ record, then global sea-level fluctuations of 20-40 m occurred during deposition of the Tangahoe Formation (Fig. 13), which is consistent with our estimates of palaeobathymetric changes from palaeoecological data (Fig. 4, 13).

It is now widely acknowledged that orbitally influenced fluctuations in the size of the Northern Hemisphere continental ice sheets controlled Late Pliocene and Pleistocene global sea-level changes (Shackleton et al. 1984). Moreover, Naish et al. (1998) presented a composite cyclostratigraphy from Wanganui Basin that provided shallow-marine evidence for most of the 48 or so fluctuations in the Northern Hemisphere ice sheets inferred from $\delta^{18} \mathrm{O}$ records (e.g., Shackleton et al. 1995). Similar shallow-marine evidence for Northern Hemisphere glacioeustasy has been described from Japan (Cronin et al. 1994; Kitamura et al. 1994), Italy (Rio et al. 1996), and California (Clifton et al. 1988).

Thus, the identification of orbitally controlled sea-level changes in the shallow-marine, mid-Pliocene sediments of Wanganui Basin is significant as these predate the development of substantial ice sheets on Northern Hemisphere continents. Recent evidence, summarised in Maslin et al. (1998), suggests that initiation of Northern Hemisphere glaciations was the culmination of a long-term high latitude cooling trend, which began in the Late Miocene with the glaciation of Greenland. Yet it is generally considered that progressive intensification of glaciation did not occur until the Greenland ice sheet expanded into northern Greenland between 3.5 and 3.0 Ma, and subsequently extended to Asia and North America between 3.0 and $2.5 \mathrm{Ma}$.

Obliquity (40 $000 \mathrm{yr}$ ) driven oscillations in $\delta^{18} \mathrm{O}$ of up to $0.6 \%$, which dominate the midPliocene period, while capable of producing c. 20-40 m sea-level changes (depending on the temperature contribution to $\delta^{18} \mathrm{O}$ signal), are generally considered too large to have been driven by oscillations in ice volume on Greenland (present day ice volume $=5.0 \mathrm{~m}$ of equivalent sea level). Therefore, one must look to the Antarctic ice sheet to explain such glacio-eustatic sea-level changes.

The terrestrial record of Pliocene ice volume change on Antarctica is highly ambiguous and contentious. One view of East Antarctic Ice Sheet behaviour presented by Webb et al. (1984) involves a dynamic and unstable cryosphere. The evidence stems from a diverse marine diatom biota incorporated into tills of Pliocene age, named the Sirius Group, that occur in a number of locations high in the Transantarctic Mountains. This led Webb et al. (1984) to propose that 
the diatomaceous sediments must have been deposited in seas in the East Antarctic interior, and thus necessitated a major deglaciation of Antarctica. The ice volume changes required by the "Webb-Harwood" hypothesis, as it became known, are inconsistent with Southern Ocean marine $\delta^{18} \mathrm{O}$ curves (e.g., Hodell \& Venz 1992; Kennett \& Hodell 1993; Shackleton et al. 1995) which, while suggestive of a warming in the earliest Pliocene, do not allow a major deglaciation of Antarctica. However, smaller scale fluctuations in Pliocene ice volume, of the order recorded in the Tangahoe Formation sequences, are consistent with the $\delta^{18} \mathrm{O}$ records.

\section{ACKNOWLEDGMENTS}

We acknowledge funding support from the New Zealand Foundation for Research, Science and Technology contracts CO5806 (GNS), UoW607 (UoW). Mike Hannah, Steve Abbott, and Chris Kendall are thanked for critical reviews that have helped focus the ideas presented in this paper. Sue Shaw (GNS) is thanked for help with drafting. Karyn Rodgers is thanked for $\mathrm{CaCO}_{3}$ analysis.

\section{REFERENCES}

Abbott ST, Carter RM 1994. The sequence architecture of mid-Pleistocene (ca. 1.1-0.4 Ma) cyclothems from New Zealand: facies development during a period of orbital control on sea level cyclicity. In: de Boer PL, Smith DG ed. Orbital forcing and cyclic sequences. International Association of Sedimentologists, Special Publication 19. Pp. 367-394.

Abbott ST, Carter RM, 1997. Macrofossil associations from Mid-Pleistocene cyclothems, Castlecliff Section, New Zealand: implications for sequence stratigraphy. Palaios 12: 188-210.

Abbott ST 1997. Foraminiferal paleobathymetry and mid-cycle architecture of mid-Pleistocene depositional sequences, Wanganui Basin, New Zealand. Palaios 12: 188-210.

Abbott ST 2000. Detached mud prism origin of highstand systems tracts from mid-Pleistocene sequences, Wanganui Basin, New Zealand. Sedimentology 47: 15-29.

Abbott ST, Carter RM 1997. Macrofossil associations from mid-Pleistocene cyclothems, Castlecliff Section, New Zealand: implications for sequence stratigraphy. Palaios 12: 188-210.

Baum GR, Vail PR 1988. Sequence stratigraphic concepts applied to Paleogene outcrops, Gulf and Atlantic basins. In: Wilgus CK et al. ed. Sea-level changes: an integrated approach. Society of Economic Paleontologists and Mineralogists, Special Publication 42. Pp. 309-329.

Beggs JM 1990. Seismic stratigraphy of the Pliocene-Pleistocene Giant Foresets Formation, Western Platform, Taranaki Basin. Proceedings of the 1989 New Zealand Oil Exploration Conference. Pp. 289-307.

Beu AG 1970. Descriptions and new species and notes on the taxonomy of New Zealand. Transactions of the Royal Society of New Zealand 7: 113-136.

Beu AG, Maxwell PA, drawings by Brazier RC 1990. Cenozoic Mollusca of New Zealand, New Zealand Geological Survey Paleontological Bulletin 58: 518.

Briggs RM, Itaya T, Lowe DJ, Keane AJ 1989. Age of the Pliocene-Pleistocene Alexandra and Ngatutura volcanics, western North Island, New Zealand, and some geological implications. New Zealand Journal of Geology and Geophysics 32: 417-427.

Browne GH, Naish TR 2003. Facies development and sequence architecture of a late fluvial-marine transition, Canterbury Plains and shelf, New Zealand: implications for forced regressive deposits. Sedimentary Geology 158: 57-86.

Buchanan J 1870. On the Wanganui Beds. Transactions of the New Zealand Institute 2: 163-166.

Butler RF 1992. Paleomagnetism. Boston, Blackwell Scientific Publications.

Cande SC, Kent DV 1995. Revised calibration of the geomagnetic polarity time scale for the Late Cretaceous and Cenozoic. Journal of Geophysical Research 100: 6093-6095.

Carter RM, Naish TR 1998. Have local stages outlived their usefulness for the New Zealand Plio-Pleistocene? New Zealand Journal of Geology and Geophysics 41: 271-279.

Carter RM, Fulthorpe CS, Naish TR 1998. Sequence concepts at seismic and outcrop scale: the distinction of physical and conceptual stratigraphic surfaces. Sedimentary Geology 122: 165-180.

Chappell J, Shackleton NJ 1986. Oxygen isotopes and sea-level. Nature 324: 137-140.

Clifton HE, Hunter RE, Gardner JV 1988. Analysis of eustatic and sedimentologic influences on transgressive and regressive cycles in the Upper Cenozoic Merced Formation, San Francisco, California. In: Kleinspehn KL, Paola C ed. New perspectives in basin analysis. Pp. 109-128. 
Cronin TM, Kitamura A, Ikeya N, Watanabe M, Kamiya T 1994. Late Pliocene climate change 3.4-2.3 Ma: paleoceanographic record from the Yabuta Formation, Sea of Japan. Palaeogeography, Palaeoclimatology, Palaeoecology 108: 437-455.

Edwards AR 1987. An integrated biostratigraphy, magnetostratigraphy and oxygen isotope stratigraphy for the late Neogene of New Zealand. New Zealand Geological Survey Report Pal 109: 73.

Fairbanks RG, Mathews RK 1978. The marine oxygen isotope record in Pleistocene coral, Barbados, West Indies. Quaternary Research 10: 181-196.

Fleming CA 1953. The geology of the Wanganui Subdivision. New Zealand Geological Survey Bulletin 52: 361 .

Forbes DL, Boyd R 1987. Gravel ripples on the inner Scotian Shelf. Journal of Sedimentary Petrology 57: 46-54.

Ghent ED 1968. Petrography of metamorphosed pelitic rocks and quartzite, Pikikiruna Range, north-west Nelson, New Zealand. Transactions of the Royal Society of New Zealand 5: 193-213.

Gillespie JL 1992. Late Quaternary carbonate-clastic sedimentation on a temperate shelf, offshore Wanganui, New Zealand. Unpublished MSc thesis, The University of Waikato, Hamilton, New Zealand.

Gillespie JL, Nelson CS 1997. Mixed siliciclastic-skeletal carbonate facies on Wanganui Shelf, New Zealand: a contribution to the temperate carbonate model. In: James NP, Clarke JDA ed. Cool-water carbonates. SEPM Special Publication 56. Pp. 127-140.

Hansen RJ, Kamp PJJ 2002. Evolution of the Giant Foresets Formation, northern Taranaki Basin, New Zealand. Proceedings of the 2002 New Zealand Petroleum Conference, Auckland. Pp. 419-435.

Hart BS, Plint AG 1993. Origin of an erosion surface in shoreface sandstones of the Kakwa Member (Upper Cretaceous Cardium Formation, Canada): importance of reconstruction of stratal and depositional geometry. In: Posamentier H, Summerhayes CP, Haq BU, Allen GP ed. Sequence stratigraphy and facies associations. International Association of Sedimentologists, Special Publication 18. Pp. 451-467.

Hay RF 1967. Sheet 7 Taranaki-Geological map of New Zealand 1:250 000. New Zealand Geological Survey.

Hayton SH 1998. Sequence stratigraphic, paleoenvironmental, and chronological analysis of the late Neogene Wanganui River section, Wanganui Basin. Unpublished PhD thesis, The University of Waikato, Hamilton, New Zealand.

Hayward BW 1986. A guide to paleoenvironmental assessment using New Zealand Cenozoic foraminiferal faunas. New Zealand Geological Survey Report, Pal 109: 73.

Hayward BW, Grenfell HR, Reid CM, Hayward KA 1999. Recent New Zealand shallow water benthic foraminifera: taxonomy, ecologic distribution, biogeography, and use in paleoenvironmental assessment. Institute of Geological and Nuclear Sciences Monograph 21. New Zealand Geological Survey Paleontological Bulletin 75: 258.

Haywick D, Henderson RA 1991. Foraminiferal paleobathymetry of Plio-Pleistocene cyclothemic sequences, Petane group, New Zealand. Palaios 6: 586-599.

Hochstetter F von 1864. Geologie von Neu Seeland. Beitrage zur Geologie der Provinzen Auckland und Nelson. Reise der Novara, Geologischer Theil 1 Bd: 1 Abt.

Hodell DA, Venz K 1992. Towards a high-resolution stable isotope stratigraphy of the Southern Ocean during the Plio-Pleistocene (4.8-0.8 Ma). In: Kennett J et al. ed. The Antarctic palaeoenvironment: a perspective of global change. Part 1. Antarctic Research Series. Washington, American Geophysical Union. Pp. 327-348.

Hunt D, Tucker ME 1992. Stranded parasequences and the forced regressive wedge systems tract: deposition during base-level fall. Sedimentary Geology 81: 1-9.

Hutton FW 1872. Synopsis of the Younger Formations of New Zealand. New Zealand Geological Survey Report on Geological Exploration 1716-1872 7: 182-184.

Hutton CO 1940. The titaniferous ironsands of Patea with an account of the residues in the underlying sedimentary series. New Zealand Journal of Science and Technology B21: 190-205.

Kamp PJJ, Vonk AJ, Bland KJ, Griffin AG, Hayton LS, Hendy AJW, McIntyre AP, Naish TR, Nelson CS 2002. Megasequence architecture of Taranaki-Wanganui-King Country Basins and Neogene progradation of two continental margin wedges across western New Zealand. Proceedings of the 2002 New Zealand Petroleum Conference. Pp. 464-481.

Kamp PJJ, Naish TR 1998. Forward modelling of the sequence stratigraphic architecture of shelf cyclothems: application to late Pliocene sequences, Wanganui Basin (New Zealand). Sedimentary Geology 116: 57-80. 
Kamp PJJ, McIntyre A 1998. The stratigraphic architecture of Late Pliocene (2.8-2.4 Ma) symmetrical shelf sequences, western Wanganui Basin, New Zealand. Sedimentary Geology 122: 53-69.

Kamp PJJ, Journeaux TD, Morgans HEG 1998. Cyclostratigraphy of mid-shelf to upper slope strata, eastern Wanganui Basin (New Zealand): correlations to the deep-sea isotope record. Sedimentary Geology 117: 165-192.

Kennett JP, Hodell DA 1993. Evidence for relative climatic stability of Antarctica during the early Pliocene: a marine perspective. Geografiska Annaler Series A. Physical Geography 75: 205-220.

Kidwell SM 1991. Condensed deposits in siliciclastic sequences: expected and observed features. In: Einsele G, Ricken W, Seilacher A ed. Cycles and events in stratigraphy. Springer-Verlag. Pp. 682-695.

Kitamura A, Kondo Y, Sakai H, Horii M 1994. 41,000 year orbital obliquity expressed as cyclical changes in lithofacies and molluscan content, Omma Formation, central Japan. Paleogeography, Paleoclimatology, Paleoecology 112: 345-361.

Kondo Y, Abbott ST, Kitamura A, Naish TR, Kamp PJJ, Kamataki T, Saul G 1998. The relationship between shellbed type and systems tract designation: examples from Japan and New Zealand. Sedimentary Geology 122: 109-128.

Laws CR 1941. Review of the Tertiary and Recent Neozelanic Pyramidellid molluscs. No. 8-The pyrgulinid genera and the genus Evalea. Transactions of the Royal Society of New Zealand 71: 6-22.

Leckie DA, Walker RG 1982. Storm- and tide-dominated shorelines in Cretaceous Moosebar-lower Gates interval: outcrop equivalents of Deep Basin gas trap in Western Canada. AAPG Bulletin 66: $138-157$.

McKnight DG 1969. Infaunal benthic communities of the New Zealand continental shelf, New Zealand Journal of Marine and Freshwater Research 3: 409-444.

Mantell GA 1848. Additional remarks on the geological position of the deposits in New Zealand which contain bones and birds. Quarterly Journal of the Geological Society 4: 238-241.

Marshall P, Murdock R 1920. The Tertiary rocks near Wanganui. Transactions of the New Zealand Institute 52: 115-128.

Marwick J 1923. The genus Glyceymeris in the Tertiary of New Zealand. Transactions of the New Zealand Institute 54: 63-80.

Marwick J 1924. The Struthiolariidae. Transactions of the New Zealand Institute 55: 155-156.

Marwick J 1926. Tertiary and Recent Volutidae of New Zealand. Transactions of the New Zealand Institute 56: 259-303.

Marwick J 1927. The Veneridae of New Zealand. Transactions of the New Zealand Institute 57: 567-635.

Maslin MA, Li XS, Loutre MF, Berger A 1998. The contribution of orbital forcing to the progressive intensification of the northern hemisphere glaciation. Quaternary Science Reviews 17: 411-426.

Miall AD 1991. Stratigraphic sequences and their chronostratigraphic correlation. Journal of Sedimentary Petrology 61: 497-505.

Milankovitch V 1998. Milutin Milankovic, from his autobiography by his son, Vasko and a preface by Andre Berger. European Geophysical Society, Katlenburg-Lindau.

Morton JE, Miller M 1968. The New Zealand sea shore. London and Auckland, Collins.

Morgans HEG, Scott GH, Beu AG, Graham IJ, Mumme TC, St George W, Strong CP 1996. New Zealand Cenozoic Timescale (version 11/96). Institute of Geological and Nuclear Sciences Science Report 96/38. Pp. 12.

Naish TR 1996: High-resolution sequence stratigraphy, sedimentology, paleoecology, and chronology of the Pliocene-Pleistocene (c.2.6-1.7 Ma) Rangitikei Group, Wanganui Basin, New Zealand. Unpublished DPhil. thesis, The University of Waikato, Hamilton, New Zealand.

Naish TR 1998. Constraints on the amplitude of late Pliocene eustatic sea-level fluctuations: new evidence from the New Zealand shallow-marine sediment record. Geology 25: 1139-1142.

Naish TR, Kamp PJJ 1997a. High-resolution sequence stratigraphy of 6th order (40 ka) Plio-Pleistocene cyclothems, Wanganui Basin, New Zealand: a case for the regressive systems tract. Geological Society of America Bulletin 109: 978-999.

Naish T, Kamp PJJ 1997b. High-resolution foraminiferal depth paleoecology of late Pliocene shelf sequences and systems tracts, Wanganui Basin, New Zealand: Sedimentary Geology 110: 237-255.

Naish TR, Abbott ST, Alloway BV, Beu AG, Carter RM, Edwards AR, Journeaux TD, Kamp PJJ, Pillans BJ, Woolfe K 1998. Astronomical calibration of a Southern Hemisphere Plio-Pleistocene reference section, Wanganui Basin (New Zealand). Quaternary Science Reviews 17: 695-710.

Nummedal D, Molenaar CM 1995. Sequence stratigraphy of ramp-setting strand plain successions: The Gallup Sandstone, New Mexico. In: Van Wagoner JC, Bertram GT ed. Sequence stratigraphy of foreland basin deposits. AAPG Memoir 64. Pp. 277-310. 
Ogilvie MJ 1993. The Plio-Pleistocene seismic stratigraphy of part of the offshore South Taranaki and South Wanganui Basins. Unpublished MSc thesis, Victoria University of Wellington, Wellington, New Zealand.

Park J 1887. On the geology of the Western Part of the Wellington Provincial District, and Part of Taranaki. New Zealand Geological Survey Report on Geological Exploration 1886-1887 18: 24-73.

Park J 1905. On the marine Tertiaries of Otago and Canterbury with special reference to the relations existing between the Pareora and Oamaru Series. Transactions of the New Zealand Institute 37: 489-551.

Pillans BJ, Roberts AP, Wilson GS, Abbott ST, Alloway BV 1994. Magnetostratigraphic, lithostratigraphic, and tephrostratigraphic constraints on Lower and Middle Pleistocene sea-level changes, Wanganui Basin, New Zealand. Earth and Planetary Science Letters 121: 81-98.

Pillans, BJ, Chappell J, Naish TR 1998. A review of the Milankovitch climatic beat: template Plio-Pleistocene sea-level changes and sequence stratigraphy. Sedimentary Geology 122: 5-23.

Plint AG 1988. Sharp-based shoreface sequences and "offshore bars" in the Cardium Formation of Alberta: their relationship to relative sea-level change. In: Wilgus CK et al. ed. Sea-level changes: an integrated approach. Society of Economic Paleontologists and Mineralogists, Special Publication 42. Pp. 357-370.

Posamentier HW, Allen GP, James DP, Tesson M 1992. Forced regressions in a sequence stratigraphic framework: concepts, examples and exploration significance. American Association of Petroleum Geologists 76: 1687-1709.

Powell AWB 1937. Animal communities of the sea bottom in Auckland and Manukau Harbours. Transactions of the Royal Society of New Zealand 66: 354-401.

Railton GL, Watters WA 1990. Minerals of New Zealand. New Zealand Geological Survey Bulletin 104: 89 .

Reineck HE, Singh I 1986. Depositional sedimentary environments. Berlin, Springer-Verlag. 439 p.

Reinson GE 1984. Barrier Island and associated strand-plain systems. In: Walker RG ed. Facies models. Geoscience Canada Series 1: 119-140.

Rio D, Channell JET, Massari F, Poli MS, Sgvetti M, D’Alessandro A, Prosser G. 1996. Reading Pleistocene eustasy in a tectonically active siliciclastic shelf setting (Crotone Peninsula, southern Italy). Geology 24: 743-746.

Saunders T, Pemberton SG 1986. Trace fossils and sedimentology of the Appaloosa Sandstone, BearpawHorseshoe Canyon Formation transition, Dorothy, Alberta. Field trip guide book. Canadian Society of Petroleum Geologists. $117 \mathrm{p}$.

Saul G, Naish TR, Abbott ST, Carter RM 1999. Sedimentary cyclicity in the marine Plio-Pleistocene of Wanganui Basin (New Zealand): sequence stratigraphic motifs of the last $2.5 \mathrm{Ma}$. Geological Society of America Bulletin 122: 524-543.

Shackleton NJ 2000. The 100000 -year ice-age cycle identified and found to lag temperature, carbon dioxide, and orbital eccentricity. Science 289: 1897-1902.

Shackleton NJ, Blackman J, Zimmerman H, Kent DV, Hall MA, Roberts DG, Schnitker D, Baldauf JG, Desprairies A, Homrighausen R, Huddlestun P, Keene JB, Kaltenback AJ, Krumsiek KAO, Morton AC, Murray JW, Westberg-Smith J 1984. Oxygen isotope calibration of the onset of ice-rafting and history of glaciation in the North Atlantic region. Nature 307: 620-623.

Shackleton NJ, Hall MA, Pate D 1995. Pliocene stable isotope stratigraphy of ODP site 846. In: Pisias N, Mayer L, Janacek T et al. ed. Proceedings of the Ocean Drilling Program Scientific Results 138: $337-353$.

Schumm S 1993. River response to base-level change: implications for sequence stratigraphy. Journal of Geology 101: 279-294.

Tiedemann R, Sarnthein M, Shackleton NJ 1994. Astronomical timescale for the Pliocene Atlantic $\delta^{18} \mathrm{O}$ and dust flux records of Ocean Drilling Program Site 659. Paleoceanography 9: 619-638.

Stipp JJ 1968. The geochronology and petrogenesis of the Cenozoic volcanics of North Island, New Zealand. Unpublished $\mathrm{PhD}$ thesis, Australian National University.

Van Wagoner JH, Posamentier HW, Mitchum RM, Vail PR, Sarg JF, Loutit TS, Hardenbol J 1988. An overview of the fundamentals of sequence stratigraphy and key definitions. In: Wilgus CK et al. ed. Sea-level changes: an integrated approach. Society of Economic Paleontologists and Mineralogists, Special Publication 42. Pp. 39-47.

Vail P 1987. Seismic stratigraphy interpretation using sequence stratigraphy. Part 1. Seismic stratigraphy interpretation procedure. In: Bally AW ed. Atlas of seismic stratigraphy. AAPG Bulletin 27: 1-10. 
Vonk A, Kamp PJJ, Hendy AW 2002. Outcrop to subcrop correlations of late Miocene-Pliocene strata, Taranaki Peninsula. Proceedings of the 2002 New Zealand Petroleum Conference, Auckland 24-27 February. www.crownminerals.govt.nz/petroleum/publications/index/

Walker RG, James NP 1992. Facies models: response to sea level change. Geological Association of Canada. 409 p.

Webb PN, Harwood DM, McKelvey BC, Mercer JH, Stott LD 1984. Cenozoic marine sedimentation and ice-volume variation on the East Antarctic Craton. Geology 12: 287-291.

Wehland F 1999. Paleomagnetic and sequence stratigraphy of the coastal Tangahoe Formation. Diplomstudiengang Geologie und Palaeontolgie, Universitaet Tuebingen, Germany.

Whitten RF 1973. The Waipipian stratigraphy and paleoecology of the South Taranaki Coast. Unpublished MSc thesis, University of Auckland, Auckland, New Zealand.

Wilson GS, Roberts A 1994. Magneto-petrogenesis in Neogene marine sediments, Wanganui Basin, New Zealand. Transactions of the American Geophysical Union 75: 124.

Woolfe K, Larcombe P, Naish TR, Purdon R 1998. Lowstand rivers need not incise the shelf: an example from the Great Barrier Reef shelf, Australia, with implications for sequence stratigraphic models. Geology 26: 75-78.

Wood LJ, Ethridge FG, Schumm SA 1993. An experimental study of the influence of subaqueous angles on coastal plain and shelf deposits. In: Weimer P, Posamentier H ed. Siliciclastic sequence stratigraphy. AAPG Memoir 58. Pp. 381-391.

Appendix 1 Lithofacies description and interpretation.

\title{
MUDSTONE ASSOCIATION (SHELF)
}

\begin{abstract}
Massive mudstone-Facies Z1
DESCRIPTION: Uncemented, blue-grey, massive to crude decimetre-scale bedded, sporadically concretionary, barren to moderately fossiliferous, bioturbated siltstone comprises a scattered moderately diverse bivalve and gastropod fauna including Lucinoma, Nemocardium, Amygdalum, Neilo, Purpurocardia, Turretellidae, Tiostrea, Chlamys, Brachiopoda, and Echinocardium spines. Common benthic foraminifers are consistent with the Nonionellina biofacies (see above) and include Nonionella flemingi, Astrononion parki, and Notorotalia finalyi. Trace fossils referable to the ubiquitous Planolites occur together with less common and locally abundant intervals of Helminthopsis, Thallasinoides, Zoophycus, and Teichichnus. This facies sporadically preserves soft sediment deformation structures in discrete intervals and may include normally-graded centimetre- to decimetre-scale fine sandstone to fine sandy siltstone beds.
\end{abstract}

INTERPRETATION: Facies Z1 mudstone represent the lowest energy conditions within the Tangahoe succession. A marine outer-middle shelf environment of deposition is indicated by the abundance of macrofauna that occupy muddy substrates in water depths between 50 and $150 \mathrm{~m}$ on the shelf in the modern marine part of Wanganui Basin (Gillespie 1992), and in the mid shelf regions of continental shelves around New Zealand generally (McKnight 1969; Beu \& Maxwell 1990). The foraminiferal fauna contained in facies Z1 are more depth specific and indicate deposition in an open marine predominantly mid-outer shelf (50-150 m depth) environment, by comparison with other Pliocene-Pleistocene (Haywick \& Henderson 1991; Naish \& Kamp 1997b; Hayward et al. 1999) and modern foraminiferal palaeoecological studies (e.g., Hayward 1986). Trace fossil taxa are indicative of the Cruziana and Zoophycus ichnofacies. Silts (muds) are interpreted to be deposited largely from suspension in offshore environments distal to sources of coarser sediment, such that only occasional, high-energy current events (e.g., storms) were able to deliver sand. Intermittent graded beds may reflect the return flow from storm surges. The abundance of body and trace fossils suggests that the seafloor and the shallow subsurface were generally oxygenated, allowing epifauna and infauna to thrive, although some localised occurrences of dark grey, sulfurous, apparently non-bioturbated siltstones suggest local or temporary development of anoxic bottom conditions. While uncommon, unstable seafloor conditions are indicated by sporadic soft-sediment deformation structures. This instability may have been imparted by seismic disturbances, cyclic wave loading, storm induced return flows, or some combination of the above.

\section{Wavy laminated mudstone-Facies $\mathbf{Z 2}$}

DESCRIPTION: Uncemented, grey, barren to sparsely fossiliferous, bioturbated, wavy-laminated, streaky fine sandy mudstone and muddy fine sandstone (silt dominated) comprise a sparse molluscan infauna dominated by Chlamys, Serratina, Zenatia, Myodora, Scalpomactra, and Echinocardium. Benthic foraminifers are dominated by the Nonionellina and Zeaflorilus biofacies and include Zeaflorilus parri, Nonionella flemingi, Notorotalia finalyi, Elphidium charlottense, Lenticulina spp., and Anomalinoides 
parvumbilia. Very fine to fine grained sandstone and mudstone are commonly interlaminated or interbedded. Sandstone beds are sharp-bound and show rare cross-stratification together with symmetrical, wave formed ripple structures.

INTERPRETATION: Facies Z2mudstone represents a marine inner shelf environment based on occurrences of macrofauna that occupy muddy to sandy substrates in water depths less than $50 \mathrm{~m}$ (Gillespie 1992), and on the inner shelf around New Zealand (McKnight 1969; Beu \& Maxwell 1990). The foraminiferal fauna contained in facies Z2 support an inner shelf interpretation for this facies, by comparison with modern foraminiferal palaeoecological studies (e.g., Hayward 1986; Hayward et al. 1999). The thinly interbbeded/interlaminated nature of the facies suggests conditions of pelagic deposition of fine grained terrigenous sediment for much of the time, punctuated by discrete depositional events in which sand is introduced. The sedimentary structures indicate sediment working by both dilute tractional currents and by waves, in most cases fair weather waves and/or possibly tidal currents. This implies either, a relatively shallow depositional setting near fair weather wave base, which for the modern Wanganui Shelf is approximately $25 \mathrm{~m}$, or a somewhat protected embayment with attenuation of tidal currents on the inner shelf, or a combination of both settings.

\section{Brecciated mudstone-Facies Z3}

DESCRIPTION: Uncemented, blue-grey, unweathered, moderately soft, barren, internally slumped and brecciated, sandy mudstone. The intraclasts are centimetre to decimetre in diameter. Soft sediment deformation is often associated with this facies.

INTERPRETATION: It is difficult to be specific about the palaeodepositional environment of facies Z3 because it contains only a sporadic mixed shelfal microfaunal assemblage, and non-diagnostic macrofauna, but it probably accumulated in a mid-inner shelf depositional environment. The presence of intraformational angular to subangular mudstone intraclasts and soft sediment deformation together with a lack of bioturbation, implies deposition was rapid and disrupted, perhaps consistent with a storm or tectonically induced sediment gravity flow on the inner shelf.

\section{Sandy mudstone-Facies Z4}

DESCRIPTION: Uncemented, blue-grey, massive to crude decimetre-scale bedded, sporadically concretionary, sparse to moderately fossiliferous, bioturbated, moderately sorted, fine sandy mudstone comprises a scattered moderately diverse soft-bottom infauna including the molluscs Gari, Scalpomactra, Atrina, and Neilo together with the epifaunal molluses Chlamys, Tiostrea, and Patro. Common foraminifers are consistent with the Zeaflorilus biofacies (see above) and include Zeaflorilus parri, Nonionella flemingi, Notorotalia finalyi, Elphidium charlottense, Lenticulina spp., and Anomalinoides parvumbilia.

INTERPRETATION: The bioturbated sandy mudstone facies Z2 typically overlies occurrences of facies Z1, or directly overlies shellbed facies (facies $\mathrm{C} 1$ and $\mathrm{C} 2$ ). It differs from facies $\mathrm{Z} 1$ in containing significantly more sand and in containing shallower marine (middle-inner open shelf) fauna. Where facies Z2 overlies facies Z1, shoaling upwards is inferred. Fine sand is incorporated into this facies during fluctuations in fair weather wave base and storms on the interface between inner and middle shelf environments. The dispersed and well mixed fine sand component of this facies is attributed to a combination of bioturbation and resuspension of sand and mud by waves and currents. The dominant foraminifer $Z$. parri is restricted to inner shelf muddy-sand substrates $(<25 \mathrm{~m})$ around the modern coastline (Hayward 1986; Hayward et al. 1999), but Naish \& Kamp (1997a) indicated a deeper water setting of up to $50 \mathrm{~m}$ for their Zeaflorilus association in late Pliocene strata in the Rangitikei Valley. We suggest mid-inner shelf water depths $(10-50 \mathrm{~m})$ for this facies.

\section{HETEROLITHIC FACIES (SHOREFACE TO ESTUARINE)}

\section{Deformed sandstone-Facies H1}

DESCRIPTION: Uncemented, brown-grey, unweathered, barren, internally slumped and deformed sandstone with intraclasts. The intraclasts are centimetre to decimetre in diameter.

INTERPRETATION: The well sorted character of this facies is consistent with a shoreface to beach palaeodepositional setting. The presence of intraformational angular to subangular mudstone intraclasts and soft sediment deformation together with a lack of bioturbation, implies deposition on the shoreface was rapid and disrupted, perhaps consistent with oversteppening of the shoreface or tectonically induced sediment gravity flows.

\section{Lenticular bedded mudstone-Facies $\mathrm{H} 2$ (see Fig. 6F)}

DESCRIPTION: Uncemented green-grey, barren, organic rich and rooted, weakly bioturbated, very sparsely fossiliferous (monospecific Austrovenus and Barrytelina) wavy to lenticular bedded/laminated mudstone. Trace fossil burrows are largely unlined circular to elliptical, probably Planolites. Vertical unlined burrows 
referable to Skolithos are rare but occur in thicker sand beds.

INTERPRETATION: The occurrence of bioturbated heterolithic muds, with organic layers and roots is consistent with an upper intertidal mudflat and supratidal salt marsh setting within an estuary or lagoon. Such an interpretation is supported by the occurrence of restricted brackish water molluscan taxa and Skolithos ichnofabric. This facies is commonly associated with the flaser bedded sands of facies H4 interpreted as intertidal sand flats. (Fig. 6F)

\section{Wavy bedded sandstone-Facies $\mathrm{H3}$}

(see Fig. 6B,F)

DESCRIPTION: Uncemented, grey-brown, sparsely to moderately fossiliferous, moderately bioturbated, wavy bedded/laminated, fine to medium sandstone is dominated by the foraminifera Ammonia beccarii and the mollusc Austrovenus stutchburyi (Fig. 6B).

INTERPRETATION: The occurrence of bioturbated heterolithic muds and sands in association with facies $\mathrm{H} 3$ and $\mathrm{H} 4$, is characteristic of the mixed flats of the intertidal region of an estuary or lagoon. Such an interpretation is supported by the occurrence of restricted brackish water molluscan taxa and Skolithos ichnofabric.

\section{Flaser bedded sandstone-Facies $\mathrm{H} 4$}

DESCRIPTION: Uncemented, grey-brown, sparsely to moderately fossiliferous, moderately bioturbated, flaser bedded, fine to medium sandstone is dominated by the foraminifera Ammonia beccarii and the mollusc Austrovenus stutchburyi. Trace fossil taxa include U-shaped and vertical burrows referable to Arenocolities and Skolithos, respectively. This facies is commonly associated with a subordinate subfacies characterised by small to medium scale bidirectional, trough cross-beds and herringbone cross-stratification.

INTERPRETATION: Facies H3 is interpreted to represent an intertidal sand flat depositional environment with migrating tidal channels and bars. Ripple cross-lamination and flaser bedding with reactivation surfaces and mud drapes are characteristic tidal sedimentary features. Bipolar cross-stratification, such as herringbone and trough cross-beds in association with high angle lateral accretion surfaces are consistent with tidal channels and point bars. The sedimentological interpretation is supported by the occurrence of restricted brackish water/estuarine macrofauna and microfauna and a restricted Skolithos ichnofabric.

\section{SANDSTONE ASSOCIATION (INNER SHELF TO BEACH)}

\section{Massive sandstone-Facies S1 \\ (see Fig. 6E,G)}

DESCRIPTION: Uncemented, grey-brown, barren to sparsely fossiliferous, bioturbated massive fine sandstone comprise the molluscan genera Gari, Scalpomactra, Panopea, Atrina, Lutraria, and Tawera, and an extremely sparse foraminiferal assemblage. A diverse trace fossil assemblage is dominated by Paleophycus, Ophiomorpha, and Planolites (Fig. 6G).

INTERPRETATION: The lack of mud and better sorting seems to suggest a shallow setting above fair weather wave base. The molluscan fauna dominate innermost shelf to lower shoreface settings in sandbottom benthic communities on the modern New Zealand shelf. Gillespie (1992) reported these taxa at water depths of 10-25 m on the modern Wanganui shelf. These facies are viewed as laying inboard of facies S3, S4, and S5 on a wave graded, open marine inner shelf to lower shoreface environment, and stratigraphically overlie these facies in the coarsening upwards and shoaling upwards regressive parts of Tangahoe sequences.

\section{Laminated sandstone-Facies S2}

(see Fig. 6G)

DESCRIPTION: Uncemented, grey-brown, barren to sparsely fossiliferous, bioturbated, low angle planar, unidirectional, cross-stratified sets of well sorted, fine sandstone. The sandstone contains a sparse beach assemblage of macrofauna including Zethalia and Fellaster. A well developed and diverse trace fossil assemblage may be preserved where bioturbation has not been too pervasive. This includes small walled cylindrical and elongate burrows referable to Macronichnus, bifurcating pelletoidal tubes referable to Ophiomorpha, lined cylindrical, horizontal Paleophycus burrows, and the ubiquitous Planolites. Metre scale scours often occur within this facies.

INTERPRETATION: Low angle unidirectional planar cross-stratified sets with cut outs and scours are common in foreshore, beach environments (Reinson 1984; Reineck \& Singh 1986). A molluscan fauna dominated by extant beach taxa such as sand dollars (Fellaster) and Zethalia is consistent with such an interpretation. Moreover, the occurrence of sparse, thick walled porcelainous foraminifera, such as Quinqueloculina, also support a beach environment of deposition. One of the most compelling lines of evidence, however, comes from the sporadic occurrences of polychaete feeding burrows, Macronichnus whose palaeoecology is determined by a stringent range of environmental parameters that occur in high energy foreshore to proximal upper shoreface environments (Saunders \& Pemberton 1986). 


\section{Hummocky cross-stratified sandstone-Facies S3}

DESCRIPTION: Uncemented, grey-brown, barren, 1-5 m wavelength swaly and hummocky laminations form hummocky cross-stratified silty fine sandstone.

INTERPRETATION: The Tangahoe Formation comprises several well expressed intervals of hummocky crossstratified sandstone often located stratigraphically between inner shelf facies Z2 and Z4 and shoreface facies S4 and S6 in coarsening upwards and shoaling upwards regressive facies assemblages. Hummocky cross-stratified sandstone is restricted to the innermost shelf and lower shoreface where strong storm surges impinge on the substrate below "fair weather wave base", due to a combination of waning storm generated return flows and storm wave action (Walker \& James 1992). Facies S3 is often interbedded with bioturbated inner shelf facies Z4 or Z1, consistent with the interpretation of storm influence below fair weather wave base.

\section{Trough cross-stratified sandstone-Facies S4}

DESCRIPTION: Uncemented, grey-brown, barren to sparsely fossiliferous, bioturbated, metre-scale, trough cross-stratified sets of well sorted, fine to medium sandstone. The sandstone contains the molluscs Zethalia, Dosinia, Lutraria, Paphies, Tawera, Scalpomactra, Maorimactra, and Fellaster. Channelled bases of trough cross-stratified sets often contain coarse grained shell lags and hash. Trace fossils include the conical-burrow Conichnus, occasional Diplocraterion, prolific Ophiomorpha tubes, and Paleophycus. This facies sporadically preserves soft sediment deformation structures.

INTERPRETATION: Unidirectional and multidirectional trough cross-beds are common in middle and upper shoreface environments (Reinson 1984; Reineck \& Singh 1986). Furthermore, facies S4 contains a diverse macrofauna that live in the breaker zone in modern New Zealand coastal environments (Morton \& Miller 1968). Trace fossils belong to upper Cruziana and Skolithos ichnofacies. The environment of deposition of S4 corresponds to an unprotected, high energy coastline in water depths of $0-10 \mathrm{~m}$.

\section{Swaly cross-stratified sandstone-Facies S5}

DESCRIPTION: Uncemented, grey-brown, barren, up to $5 \mathrm{~m}$ thick, $1-5 \mathrm{~m}$ wavelength swaly and hummocky laminations form swaly cross-stratified fine sandstone (no mudstone interbeds).

INTERPRETATION: Swaly cross-stratified sandstone facies typically occur stratigraphically above facies S3 and are interpreted to form in a generally shallower more agitated depositional environment where there is little opportunity for mud deposition (Leckie \& Walker 1982) on the lower shoreface.

\section{Large scale trough cross-stratified (pebbly) sandstone-Facies S6}

DESCRIPTION: Brown-grey, sparsely fossiliferous to fossiliferous, bioturbated, moderate $(1-5 \mathrm{~m})$ to large scale (tens of metres), trough cross-stratified (dune-forms) pebbly medium to coarse sandstone with mud drapes and reactivation surfaces comprise a diverse range of abraded, reworked and new distarticulated molluscan fossil material dominated by Paphies, Nucula, Xymene, and Cyclomactra. Coarse sand and pebbles are composed of pumice, volcanic lithics, crystals (hornblende, quartz and feldspar), greywacke, and shell hash.

INTERPRETATION: These cross-bedded sands display superimposed bidirectional trough cross-beds, with mud drapes, channel fill trough cross-stratification, superimposed flaser and lenticular lamination in interdune mudstone, greywacke pebbles and estuarine to inner shelf fauna that are disarticulated, redeposited, and abraded indicating a hydrodynamically active channel and bar dominated, shallow-marine substrate with fluctuating current speeds, and probably large subtidal to intertidal channels connecting coastal embayments with the open continental shelf. The dominant macrofauna are the intertidal taxa Paphies, Nucula, Xymene, and Cyclomactra.

\section{Massive to ripple cross-stratified sandstone-Facies S7}

DESCRIPTION: Uncemented, grey-brown, barren to sparsely fossiliferous, bioturbated, well sorted, massive to asymmetrical (current) and symmetrical (wave), ripple cross-stratified fine sandstone with occasional mud intraclasts (Fig. 6E). Trace fossils include the conical-burrow Conichnus, occasional Diplocraterion, prolific Ophiomorpha tubes, and Paleophycus. This facies sporadically preserves soft sediment deformation structures.

INTERPRETATION: Combined flow sedimentary structures containing both oscillatory (wave) and unidirectional (current) ripples are commonplace on open coastline, storm influenced shoreface environments (Forbes \& Boyd 1987; Hart \& Plint 1993). Furthermore, facies S7 often occurs in association with facies S1 and S2 and contains a diverse macrofauna (including, Gari lineolata, Scalpomactra, Divaricella, Tawera, Nucula, and Chlamys) that live immediately seawards of the breaker zone in modern New Zealand coastal environments (Morton \& Miller 1968). Trace fossils belong to upper Cruziana and Skolithos ichnofacies. 


\title{
SHELLBED ASSOCIATION (MIDDLE SHELF TO SHOREFACE)
}

\author{
Shellbed-Facies C1 \\ (see Fig. 6A,C)
}

DESCRIPTION: Loosely packed to closely packed molluscan and brachiopod shells (Gari, Scalpomactra, Bassina, Dosinia, Barnea, Mactra, Tawera, Chlamys, Divaricella, Lutraria, and Tiostrea in sandy substrates; Chlamys, Patro, Tiostrea, Pleuromeris, Purpurocardia, Tawera, Limaria, Glycymerula, Tucetona, Barbatia, Neothyris, Bryozoa, and Brachiopoda in muddy substrates) are supported within bioturbated terrigenous sandstone or siltstone matrix. This facies is matrix supported and contains between 15 and $35 \%$ (by weight) carbonate.

\section{Cross-stratified pebbly shellbed-Facies $\mathrm{C} 2$}

(see Fig. 6C)

DESCRIPTION: Closely packed, cross-stratified shell-pebble conglomerate or pebbly sandstone containing a mixed fauna of abraded and worn shells and shell fragments from estuarine, open shoreface, and shelfal environments, is supported within a coarse sand and/or gravel mixed carbonate-siliciclastic matrix. It may also include mud drapes. This facies is matrix supported and contains between 15 and $35 \%$ (by weight) carbonate.

\section{Fossiliferous siltstone and sandstone-Facies C3 (see Fig. 6A)}

DESCRIPTION: Bands, clumps, and scattered in situ or near situ molluscan shells are supported within bioturbated terrigenous sandstone (Tawera, Panopea, Scalpomactra, Zethalia, Fellaster, Paphies, Myadora, Dosinia, Austrovenus, Cyclomactra, Barnea, Xymene, Maoricolpus, and Atrina), or siltstone (Neilo, Tiostrea, Serritina, Echinocarium, Zenatia, and Chlamys) matrix. This facies is matrix supported and contains less than $10 \%$ (by weight; acid digestion) carbonate.

INTERPRETATION: See Table 2. Macrofaunal and microfaunal composition together with the occurrence of fine grained terrigenous matrix indicates accumulation of facies $\mathrm{C} 1$ in a low energy inner to mid shelf environment under conditions of relative sediment starvation. Low terrigenous sediment input is indicated by the thinness of facies $\mathrm{Cl}$ units and the occurrences of a diverse epifaunal benthos. A high proportion of articulated bivalves in life position along with a general lack of hydraulic sorting features (i.e., cross-bedding) indicates that this facies accumulated below the contemporary storm wave base. While facies $\mathrm{C} 3$ is compositionally similar to facies $\mathrm{C} 1$, it is comparatively less fossiliferous and reflects accumulation on the innermost to mid shelf under conditions of higher terrigenous sediment input. Sandy shellbed facies $\mathrm{C} 1$ is the inner shelf to shoreface lateral equivalent of offshore silty shellbed facies $\mathrm{C} 1$. Sandy shellbeds of facies C3 are the inner shelf lateral equivalent of offshore siltstone shellbeds, and reflect accumulation on the inner shelf of a sandy, matrix supported shell rich deposit under conditions of relatively high sediment input, compared with the environmentally similar, but more condensed shellbeds of facies $\mathrm{C} 1$. Cross-stratified mixed siliciclastic-carbonate conglomerates (facies C3) scoured into other shoreline facies contain reworked contemporaneous shoreface/inner shelf fauna along with older abraded and rounded shells and pebble sized intraclasts of siltstone, sandstone, and coquina, which were probably supplied by rivers or derived from erosion of older strata in coastal cliffs.

Appendix 2 A summary of the sequence stratigraphic model applied in this paper.

In stratigraphic order, the important sediment-bounding surfaces are the lower sequence boundary, the transgressive surface of erosion (TSE), the downlap surface (DLS), the regressive surface of erosion (RSE) and the upper sequence boundary (Fig. 7). Sequence boundaries are often represented by TSEs, sharply planed surfaces of marine erosion produced during shoreline transgression that typically remove evidence of the lowstand subaerial unconformity and associated non-marine terrestrial sediments. When overlying siltstone, TSEs are often penetrated by pholad borings with shells sometimes preserved in borings; when on sandy substrate, the boundaries are often penetrated by Ophiomorpha and other burrows. Each sequence boundary is overlain by shallow-marine, transgressive systems tract (TST) sands or by a transgressive shell lag or reworked onlap shellbed. A superjacent backlap shellbed (mid-cycle shellbed of Abbott \& Carter 1994) comprising relatively offshore, deeper water fauna overlies the lower TST sediments and is often separated by a flooding surface, which represents the highest rate of relative sea-level rise during the transgression. The top of this backlap shellbed is marked by a downlap surface (DLS), a rapidly gradational contact with siltstone of the overlying highstand systems tract. Conceptual horizons corresponding to maximum flooding surface, peak eustatic sea level and peak relative sea level may occur in the upper parts of TST or the lower parts of the HST (Carter et al. 1998). A downlap shellbed may occur immediately above the DLS within the distal, basinward portion of progradational siliciclastic sediments of the highstand systems tract. Highstand sedimentation is considered to occur 
between the late rise and early fall of the relative sea-level cycle. The uppermost component of Wanganui sequences is the regressive systems tract (RST). The lower bounding surface of the RST is abruptly gradational in the late Pliocene sequences exposed in Rangitikei and Turakina sections, and is marked by a rapid upward shoaling. However, in the mid-Pliocene Tangahoe Formation this surface is often erosional and marks abrupt dislocation across which inner shelf muddy facies are unconformably overlain by sandy shoreface facies representing rapid seaward displacement of the nearshore sediment wedge. This surface, referred to as the regressive surface of erosion (RSE; Plint 1988), is considered to reflect wave base erosion and sediment bypassing during eustatically-"forced" regression. In seismic data, RST parasequences are markedly more progradational than those of the HST, and are downstepped or inclined towards the basin (e.g. Browne \& Naish 2003). The upper-bounding surface of the RST is the sequence boundary. 